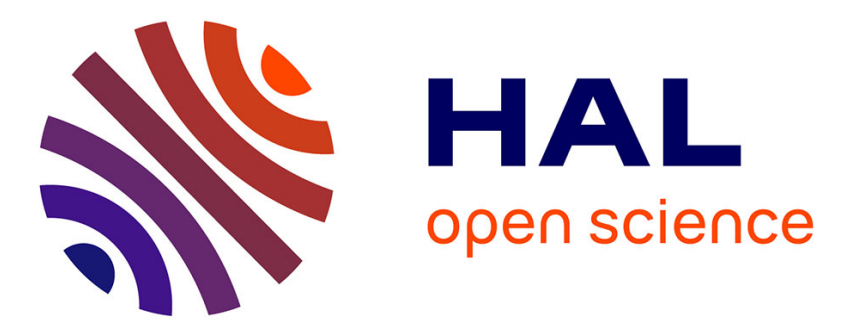

\title{
Evaporitic brines and copper-sulphide ore genesis at Jbel Haïmer (Central Jebilet, Morocco)
}

Samira Essarraj, Marie-Christine Boiron, Michel Cathelineau, Chantal Peiffert

\section{To cite this version:}

Samira Essarraj, Marie-Christine Boiron, Michel Cathelineau, Chantal Peiffert. Evaporitic brines and copper-sulphide ore genesis at Jbel Haïmer (Central Jebilet, Morocco). Ore Geology Reviews, 2020, pp.103920. 10.1016/j.oregeorev.2020.103920 . hal-03109372

\section{HAL Id: hal-03109372 \\ https://hal.univ-lorraine.fr/hal-03109372}

Submitted on 8 Feb 2021

HAL is a multi-disciplinary open access archive for the deposit and dissemination of scientific research documents, whether they are published or not. The documents may come from teaching and research institutions in France or abroad, or from public or private research centers.
L'archive ouverte pluridisciplinaire HAL, est destinée au dépôt et à la diffusion de documents scientifiques de niveau recherche, publiés ou non, émanant des établissements d'enseignement et de recherche français ou étrangers, des laboratoires publics ou privés.

\section{(ㅇ)(1) $\$$}

Distributed under a Creative Commons Attribution - NonCommercial - NoDerivatives $\mid 4.0$ 
1 Evaporitic brines and copper-sulphide ore genesis at Jbel Haïmer (Central Jebilet, Morocco)

2

3

4

5

Samira Essarraj ${ }^{1 *}$, Marie-Christine Boiron ${ }^{2}$, Michel Cathelineau ${ }^{2}$ and Chantal Peiffert ${ }^{2}$

6

7 1: Laboratoire Géoressources, Faculté des Sciences et Techniques, Université Cadi Ayyad, BP

8 549, Marrakesh, Morocco.

9

2: Université de Lorraine, CNRS, CREGU, GeoRessources, F-54000 Nancy, France.

10

11

12

13

14

15

16

17

*: corresponding author. s.essarraj@uca.ac.ma

18

19

20

21

22

23 


\section{Abstract}

The Jbel Haïmer copper-sulphide mineralisation occurs at $20 \mathrm{~km}$ north of Marrakesh in the Variscan Jebilet massif, Morocco. Most of the ores (up to 3.9 wt. $\% \mathrm{Cu}, \leq 38 \mathrm{ppm} \mathrm{Ag}$, and up to $2.9 \mathrm{ppm} \mathrm{Au}$ ) occur as impregnations of NE-SW fault/fracture zones and related tectonic breccia. Two independent stages of fluid circulation and mineral deposition are distinguished. First, Late Variscan high temperature-low pressure metamorphism synchronous of granite intrusion induced percolation of $\mathrm{C}-\mathrm{H}-\mathrm{O}-\mathrm{N}$ hydrothermal fluids throughout faults and shear zones. The drop in pressure from lithostatic down to hydrostatic values at temperatures around $350 \pm 50^{\circ} \mathrm{C}$ triggered quartz precipitation associated with minor $\mathrm{Sn}-\mathrm{As}-(\mathrm{Co}-\mathrm{Ni})$ deposits and finally brecciation. The second stage, more recent than Triassic, consists in the deposition of quartz + carbonates, followed by $\mathrm{Cu}-(\mathrm{Pb}-\mathrm{Zn})$ sulphides $( \pm \mathrm{Ag}-\mathrm{Au}$ alloys $)$ in fractures crosscutting $240 \mathrm{Ma}$ microdiorite dikes. Mixing of evaporitic brines likely coming from Triassic formations with low salinity aqueous fluids was responsible for $\mathrm{Cu}$-sulphide deposition at temperatures of around $220-280^{\circ} \mathrm{C}$ at a depth of $4-5 \mathrm{~km}$. These base metal-rich brines are similar to those from the nearby Roc Blanc Ag-deposit and several other silver and base metal deposits in Morocco, considered as having circulated during the Central Atlantic Ocean opening.

Keywords: $\mathrm{Cu}-(\mathrm{Ag})$ ores, brines, fluid mixing, Triassic evaporite, Atlantic rifting 


\section{Introduction}

Granite-related ore systems, an essential target for the mineral exploration industry (Sial et al., 2011), were developed as models for several commodities such as Au and W-Sn (granite related Au-deposits (IRGDs) for instance: Thompson et al., 1999; Hart, 2007; Thompson and Newberry, 2000; Lang and Baker, 2001). The proximity of the deposits to intrusions or inferred intrusions marked by contact metamorphic aureoles was one of the main arguments for such ore deposit models where magmatism plays a significant role at less as a source of heat flow for fluid convection. In Morocco, base metal ( $\mathrm{Pb}-\mathrm{Zn}-\mathrm{Cu}$ ), and precious metal (such as $\mathrm{Ag}$ ) deposits are however not coeval with Pan-African or Variscan orogenies and related granitoids. Thus, extensional tectonics associated with the successive stages of Atlantic rifting favoured the formation of $\mathrm{Ag}$ and $\mathrm{Pb}-\mathrm{Zn}$ deposits in Morocco and Western Europe. Ore deposits formed either in the Mesozoic sedimentary cover or in the basement where inherited discontinuities are excellent pathways for sedimentary brines. There, the increased porosity and permeability of damaged zones developed around faults and shear zones favoured fluid flows (Boiron et al., 2010; Nadoll et al., 2019).

In the Variscan Jebilet massif (Morocco), several vein-type polymetallic deposits occur in close spatial association with Late Variscan plutons such as the Roc Blanc Ag-( $\mathrm{Zn}-\mathrm{Pb})$ deposit where Ag grades reach 500 - 700 ppm or the Jbel Haïmer Cu occurrences (Huvelin, 1977). Huvelin (1977) considered these deposits as related to magmatic intrusions. At Roc Blanc, the model recently proposed by Essarraj et al. (2017a) is very different because it considers that the introduction of silver is late and not related to the Variscan cycle but synchronous to the Atlantic rifting after Triassic times. The silver deposit was there superimposed on previous Variscan mineral assemblages (sulphides and sulpharsenides) and related to the downward circulation of basinal brines. 
At Jbel Haïmer, located at most 500 metres from the Roc Blanc deposit, a series of copper occurrences have been mined before the $\mathrm{XX}^{\text {th }}$ century only in the near-surface weathered part. Copper was exploited in metre-sized excavations as malachite in breccia affected by intense oxidation. Oxidised ore breccia from outcrops at Jbel Haïmer have $\mathrm{Cu}$ grades up to $3.9 \%$ (average $0.6 \%$ ), up to $38 \mathrm{ppm} \mathrm{Ag,} \mathrm{and} 0.5$ ppm to locally 2.9 ppm Au (Krutilin et al., 2013). The average $\mathrm{Cu}$ grade of the Jbel Haïmer ore is similar to those from volcanogenic massive sulphide deposits that occur a few kilometres towards the South-West and North-West, such as the Draa Sfar deposit $(0.5$ wt. \% Cu), and the Kettara abandoned mine $(0.6$ wt. \% Cu). There, $\mathrm{Cu}$-rich quartz-carbonate veins crosscut volcanogenic massive sulphide (Outigua et al., 2020; N'Diaye et al., 2016).

The present study aims to decipher the nature of the mineralising fluids in the Jbel Haïmer Cudeposit, in particular the temporal and spatial relationships between the mineralisation and the geodynamic events. The objective was to test a potential generalisation of the Roc Blanc genetic model developed for Ag-ores to other base metals such as copper in the Central Jebilet.

\section{Regional geology}

Variscan units and tectonic-metamorphic stages: The Jebilet massif extends $170 \mathrm{~km} \mathrm{E-W}$ and 7 to $40 \mathrm{~km} \mathrm{N-S} \mathrm{(Fig.} \mathrm{1),} \mathrm{and} \mathrm{consists} \mathrm{of} \mathrm{three} \mathrm{lithotectonic} \mathrm{domains,} \mathrm{the} \mathrm{Western,} \mathrm{Central,} \mathrm{and}$ Eastern Jebilet, separated by first-order shear zones: the Marrakesh Shear Zone (MSZ), between the Eastern and Central Jebilet (Lagarde and Choukroune, 1982) and the West Moroccan Shear Zone (WMSZ) between the Western and the Central Jebilet (Huvelin, 1977; Piqué et al., 1980; Lagarde and Choukroune, 1982; Le Corre and Bouloton, 1987) (Fig. 1b). According to Huvelin (1977) and Aarab and Beauchamp (1987), this massif is an intra-continental rift-basin filled with marine sediments deposited in an anoxic environment (Beauchamp, 1984; Beauchamp et al., 1991) from the Late Devonian to Early Carboniferous. During this extensional tectonic 
regime, cogenetic tholeiitic mafic-ultramafic and calc-alkaline felsic intrusions are the witnesses of the pre-orogenic bimodal magmatism (Bordonaro, 1983; Aarab, 1984) (Fig. 2a). Recent U-Pb LA-ICP-MS dating on zircon from granodioritic plutons gave an absolute age of $358 \pm 7 \mathrm{Ma}$ (Tabouchent - Bamega) and $336 \pm 4 \mathrm{Ma}$ (Oulad Ouaslam) (Delchini et al., 2018). This age range is older than the former ages obtained for the same rocks $(330.5 \pm 0.7 \mathrm{Ma}$, U$\mathrm{Pb}$ on zircons, Essaifi et al., 2003; and $327 \pm 4 \mathrm{Ma}$, Rb-Sr on whole rock, Mrini et al., 1992). These intrusions produced contact metamorphism (M1) in the pyroxene-hornfels facies (Huvelin, 1977; El Hassani, 1980; Delchini et al., 2018). The Jbel Haïmer Cu-ore bodies occur in the central part of the Jebilet comprised of the so-called Sarhlef series (Fig. 1). The Sarhlef metasediments deposited in the rift-basin as a thick succession of argillites overlain by carbonaceous argillites and limestones (Bordonaro, 1983). These series have a Carboniferous age (Upper Visean - Namurian: fossil relative dating by Posidonomya becheri Bronn; Huvelin, 1961). In the Sarhlef series, stratabound lenticular $\mathrm{Fe}-\mathrm{Cu}-\mathrm{Pb}-\mathrm{Zn}$ volcanogenic massive sulphides formed during this rifting period (Huvelin, 1977). The structural features of the Jebilet massif are due to the succession of two deformation events, D1 and D2 that lasted from the Late Carboniferous to the Early Permian and constituted the Variscan orogeny (Delchini et al., 2018). During the D1 compressive deformation, the emplacement of superficial allochthonous nappes resulted in recumbent folds (Delchini et al., 2018), accompanied by rare schistosity cleavage S1, boudinage of competent layers as well as vertical fractures and veins. The context is typical of a diagenetic to anchizonal metamorphism transition (low temperature: $150-200^{\circ} \mathrm{C}$, Bamoumen, 1988). The D1 structures trending E-W in the Central Jebilet and the West of the Eastern Jebilet suggest an N-S shortening (Delchini et al., 2018). The D2 is the major polyphase deformation event that corresponds to a WNW-ESE to NW-SE transpressional crustal shortening. During the first D2 stage, NS-N30 ${ }^{\circ} \mathrm{E}$ kilometre-size isoclinal folds developed, as well as a penetrative S2 cleavage and a high temperature-low pressure (HT-LP) thermal 
metamorphism (greenschist to amphibolite facies; 4 to $5 \mathrm{kbar}$ and $560-485^{\circ} \mathrm{C}$; Delchini et al., 2016). The second stage of D2 deformation corresponds to transpressional shearing that induced shear zones at all scales, in particular the multi-kilometre-sized WMSZ and the MSZ (Fig. 1b). HT-LP thermal metamorphism M2, so-called M2a in Delchini et al. (2018), isoclinal folding D2, high thermal gradients $\left(50^{\circ} \mathrm{C} / \mathrm{km}\right.$, and up to $\left.95^{\circ} \mathrm{C} / \mathrm{km}\right)$ and shear zone activity occurred within the 310-280 Ma period (Delchini et al., 2018). Close to MSZ, leucogranites such as the Bramram intrusion (Fig. 2a) at $295 \pm 15 \mathrm{Ma}$ (Rb/Sr, Mrini et al., 1992) and $297 \pm 6$ Ma (Tisserant, 1977) intruded the Sarhlef schists. Local contact metamorphism (noted M2b in Delchini et al., 2018) reached hornblende-hornfel facies with peak conditions about 2-3 kbar and $620^{\circ} \mathrm{C}$ (El Hassani, 1980; Delchini et al., 2016) and locally induced the development of graphite-rich skarns (Fig. 2a) in the Central Jebilet (Bastoul, 1992). The HT-LP metamorphism coeval with leucogranite intrusions may be explained by the inversion of the thermally weakened intracontinental domain during the Variscan compression D2 (Delchini et al., 2018). A final increment of the D2 stage corresponds to the development of a network of regional brittle conjugate shear zones and brittle reverse faults (ENE, and NW) that locally deform the S2 major cleavage (Delchini et al., 2018). The Aït Bella OuSaïd kilometre-sized fault located close to Jbel Haïmer (few hundred metres to the North, Fig. 2a) is one of the longest and thickest ENE shear zones resulting from the last D2 stage (Delchini et al., 2018).

Post-Variscan microdiorite dikes and sills: they crosscut both the bimodal magmatic and granodioritic rocks and leucogranite plutons. They may exceed $1 \mathrm{~km}$ in length, strike N-S to $\mathrm{N} 40^{\circ} \mathrm{E}$ (Fig. 2a). They formed during a period of distension (Huvelin, 1977; Bordonaro, 1983; Aarab and Beauchamp, 1987; Bernard et al., 1988; Bouloton and Gasquet, 1995; Essaifi et al., 2003; Dostal et al., 2005) at ca. $240 \pm 10 \mathrm{Ma}$ (K-Ar method on kaersutite: Gasquet and Bouloton, 1995; Youbi et al., 2001; Dostal et al., 2005, summarised by Bouloton et al., 2019). They are synchronous with the thermal events which affected the Western Meseta in the 250- 
210 Ma range (apatite fission track thermal modelling: Ghorbal et al., 2008; Saddiqi et al., 2009; Barbero et al., 2011).

Mesozoic sedimentation and deformation: several extensional deformation events occurred from lower Triassic to Post-Kimmeridgian times. Such events are coeval with the break-up of Pangea and Central Atlantic opening (Medina, 1991; Jalil, 1999; Tourani et al., 2000; Medina et al., 2001; El Arabi, 2007). Subsequently, the deposit of thick clastic series alternating with evaporites and basaltic flows, filled large sedimentary basins. In this time, the Central Jebilet domain was a part of the West Moroccan Arch (WMA: Hafid, 2006; El Arabi, 2007; Saddiqi et al., 2009). The latter was a paleogeographic high separating Tethyan domain to the East, i.e., the High Atlas rift and the Atlantic rift to the West. Paleogeographic reconstructions and apatite fission-track data (Saddiqi et al., 2009) showed that the Central Jebilet high was supplied by sediments that did not exceed $2.4 \mathrm{~km}$ in thickness, an estimate slightly lower than that proposed by Ghorbal et al. (2008). Triassic series, composed of sandstone, argillites, and evaporites (gypsum and salt), are outcropping at the Southern limit between Central and Eastern Jebilet (Fig. 2a) as well as in the Western Jebilet (Huvelin, 1977). The pre-Atlasic orogenic period lasted from the Triassic to the Late Cretaceous. From a structural point of view, the parallelism of some major Paleozoic trends (NNE, High and Middle Atlas) attests to the reactivation of former structures during the Atlasic orogeny at the Eocene (Frizon de Lamotte et al., 2008). Nevertheless, the E-W striking fault systems that crosscut older Paleozoic structures in the Jebilet did not correspond to reactivated structures (Frizon de Lamotte et al., 2008). Those newly formed E-W fracture sets are filled with quartz-carbonate and contain $\mathrm{Cu}$ and $\mathrm{Pb}-\mathrm{Zn}$ $(\mathrm{Cu})$ ores (Huvelin, 1977).

The Jbel Haïmer Cu-ore deposit: At Jbel Haïmer, $\mathrm{Cu}$ ore bodies (Fig. 2b) are hosted by greenish-brown to grey Sarhlef schists, split in millimetre thick sheets (S1). Intercalations of sandy schist and sandstone layers prevail as NE-SW protruding crests at most one metre thick 
and a few tens of metres long. Grey quartz occurs as boudinaged lenses in the schistosity planes, derived from metamorphic exsudation. Sarhlef series sometimes present hornfels with cordierite spots produced by contact metamorphism during granodiorite intrusions (Huvelin, 1977). Granodiorites outcrop a few kilometres to the South of Jbel Haïmer (Fig. 2a). Besides, contact metamorphism locally transformed sandstones to quartzite. The latter shows granoblastic mosaic texture and presents millimetre-sized impregnations and veinlets of darkbrown tourmaline and hyaline quartz that crosscut the schist. When approaching granodiorite, tourmaline abundance increases up to massive black tourmalinite. Several microdiorite dikes ( $<1 \mathrm{~m}$ in width and up to one hundred metres in length) are widespread in the Jbel Haïmer outcrops and throughout the mineralised areas (Fig. 2a).

Ore zones occur exclusively in breccia affecting competent formations such as sandy schist and sandstone - quartzite layers (Fig. 3a to 3c). The old mining works are no longer accessible in Jbel Haïmer and were confined to a few tens of metres depth over the water table (up to $50 \mathrm{~m}$, Huvelin, 1977). Most ores are therefore malachite and Fe-oxide impregnations in the oxidised breccia (Fig. 3a to 3e) and locally in the brecciated microdiorite dikes (Fig. 3f, 3g).

\section{Methods}

Representative samples were collected from the wall rocks (spotted schist, sandy schistsandstone, and microdiorite dikes), as well as from the ore breccia and quartz veins for this study. Petrographic and scanning electron microscope (SEM) investigations were carried out using twenty selected samples.

Nine doubly polished wafers were used for fluid inclusion studies. Fluid inclusion typology (Table 2) follows notations from Boiron et al. (1992): aqueous (w), carbonic (c), bulk homogenisation to the liquid phase $(\mathrm{L})$, bulk homogenisation to the vapour $(\mathrm{V})$, presence of halite cube (h), and unidentified solids (s). Microthermometry was performed using a Linkam 
THSMG600 freezing-heating stage (Shepherd, 1981). Abbreviations follow the convention from Roedder (1984) for microthermometric data presentation: $\mathrm{Tm}^{\mathrm{CO}} 2$ : melting temperature of volatile phase for carbonic fluid inclusions, $\mathrm{Th} \mathrm{CO}_{2}$ : homogenisation temperature of volatile phase for carbonic fluid inclusions, Te: eutectic or apparent eutectic temperature defined as the temperature at which the first liquid appears in the frozen fluid inclusion during lowtemperature measurements, Tm hh: temperature of final melting of hydrohalite, Tm ice: final melting temperature of ice, Tm cl: melting temperature of clathrate, Th ( $\mathrm{L}$ or $\mathrm{V})$ : total homogenisation temperature ( $\mathrm{L}+\mathrm{V}$ to liquid or $\mathrm{L}+\mathrm{V}$ to vapour phase respectively) and $\mathrm{Tm}$ $\mathrm{NaCl}$ : melting temperature of halite cube). The precision of phase transitions below $0^{\circ} \mathrm{C}$ was $+0.2^{\circ} \mathrm{C}$, whereas the precision of the liquid-vapour homogenisation was $1^{\circ} \mathrm{C}$. Over the range 90 to $0^{\circ} \mathrm{C}$, the accuracy was $0.4^{\circ} \mathrm{C}$, and from 0 to $300^{\circ} \mathrm{C}$ was $2^{\circ} \mathrm{C}$. For most aqueous fluid inclusions, salinity calculations have been made in the $\mathrm{H}_{2} \mathrm{O}-\mathrm{NaCl}$ system using data from Bodnar and Vityk (1994) based on Tm ice or Tm halite for fluid inclusions containing halite cube (when $\mathrm{Tmh}<\mathrm{Th}$ and no Tm hh is available). When both $\mathrm{Tm}$ ice and $\mathrm{Tm}$ hh or $\mathrm{Tm} \mathrm{NaCl}$ values were available, salinity was calculated in the $\mathrm{H}_{2} \mathrm{O}-\mathrm{NaCl}-\mathrm{CaCl}_{2}$ system using data from Steele-MacInnis et al. (2011).

Molar fractions of gas components $\left(\mathrm{CO}_{2}, \mathrm{CH}_{4}, \mathrm{~N}_{2}\right)$ were determined on individual carbonic and aqueous-carbonic fluid inclusions in quartz by Raman spectrometry analysis using a DILOR LABRAM Raman spectrometer at the GeoRessources laboratory, University of Lorraine, Nancy, France. Bulk composition, molar volume, volatile/water ratio, and salinity were calculated from the $P-V-T-X$ properties of individual fluid inclusions in the C-O-H-S system (Dubessy, 1984; Dubessy et al., 1989; Thiery et al., 1994; Bakker, 1997). Isochores were calculated using the program ISOC from the computer package FLUIDS-1 (Bakker, 2003). Laser ablation - inductively coupled plasma - mass spectrometry (LA-ICP-MS) analyses have been performed at the GeoRessources Laboratory (Nancy, France) on individual fluid 
inclusions to quantify the ionic composition of fluids involved in the metal deposition. Laser ablation was carried out with an ESI New Wave Research UC $193 \mathrm{~nm}$ excimer laser at $5 \mathrm{~Hz}$ laser frequency. The ablated material was analysed with an Agilent 8900 Triple Quadrupole ICP-MS, equipped with a collision-reaction cell. The ablated material was carried in helium gas (0.5 1 min-1), which was mixed with argon (0.9 1 min-1) via a cyclone mixer (volume of $9.5 \mathrm{~cm}^{3}$ ) before entering the ICP torch. A straight ablation technique with spot sizes of 30 and $40 \mu \mathrm{m}$ was applied to obtain overall higher signal-to-background intensity ratios and lower limits of detection (LOD). Each analytical series consists in the following isotopes: ${ }^{23} \mathrm{Na},{ }^{24} \mathrm{Mg}$, ${ }^{39} \mathrm{~K},{ }^{44} \mathrm{Ca},{ }^{55} \mathrm{Mn},{ }^{57} \mathrm{Fe},{ }^{63} \mathrm{Cu},{ }^{66} \mathrm{Zn},{ }^{75} \mathrm{As},{ }^{85} \mathrm{Rb},{ }^{87} \mathrm{Sr},{ }^{109} \mathrm{Ag},{ }^{121} \mathrm{Sb},{ }^{137} \mathrm{Ba}$ and ${ }^{208} \mathrm{~Pb}$. The collected intensity ratios for $\mathrm{Na}$ were converted to concentration ratios by external calibration against a NIST 610 standard reference glass following a bracketing standardisation procedure (Longerich et al., 1996). ${ }^{23} \mathrm{Na}$ was used as an internal standard to calculate absolute concentrations and was obtained via microthermometry. The calculation method for the chemical composition of the fluid inclusions is based on a combination of the ice-melting temperature, a Pitzer-based thermodynamic model, and the LA-ICP-MS Na/cation ratios (Leisen et al., 2012a). Limits of detection for a given element can be calculated, according to Longerich et al. (1996) and described in Leisen et al. (2012a).

\section{Barren and ore veins in their geological context}

The schistosity cleavage (S1) in the Sarhlef series strikes N30-50 ${ }^{\circ}$ with an average dip of 20$60^{\circ}$ to the East (Fig. 4a, 5a). Joints and faults are mostly parallel to the schistosity or crosscutting it (Boutira and Hakkou, 2012; Essarraj et al., 2013; Fig. 4, Fig. 5).

Barren veins: fractures, a few centimetres to a few metres in length, form a dense network striking NW-SE (average N130-140 ${ }^{\circ}$ ), dipping 50 (East and West) to sub-vertical. Pale grey quartz QI infillings are found in fractures crosscutting competent sandy schist and sandstone 
and are associated with chlorite along the vein walls (Fig. $4 \mathrm{~b}, 5 \mathrm{~b}$ to $5 \mathrm{e}$ ). The second set of fractures and white quartz veins named QII, in general up to a few metres long, strikes from N $160^{\circ}$ E to NE-SW and crosscuts the NW-SE QI veins (Fig. 5d) and fractures. The veins show a geodic texture locally. Decametre length corridors of breccia are oriented N10-30 ${ }^{\circ}$ to NESW (Fig. 3a to 3e, 4) with an average dip around $60^{\circ}$ to the East, and affect all preceding quartz types. They correspond to open structures sub-parallel to the strike of the regional schistosity, although schistosity planes are difficult to be observed in sandy schist and sandstone layers (Fig. 3a, 3c). Microdiorite dikes intruded the schist parallely to the ore breccia corridors, as they strike mostly NNE-SSW (Fig. 4). They are locally deformed in particular along the breccia corridor (Fig. 3g).

Quartz-carbonates veins and Cu-ore bodies: a set of E-W fractures, feathery quartz and carbonate veins crosscut the schist and sandstone layers, as well as the microdiorite and most earlier veins above described (Fig. 5f, 5g). The $\mathrm{Cu}$ - ores formed later than $\mathrm{E}-\mathrm{W}$ fractures and crosscut as well as the microdiorite. They are found as infillings of new microfracture sets in the vicinity of the main ore breccia corridor.

\section{Mineralogy}

Table 1 provides the paragenetic succession.

Pre-ore stage: A biotite-tourmaline-pale-grey quartz QI assemblage constitutes the first stage of barren vein infillings. Biotite, with tourmaline crystals, are abundant and consistently line the QI vein walls (Fig. 6a, 6b). Biotite was almost totally replaced later on by chlorite (chlorite 1). The pale-grey quartz QI is coarse-grained and intensively sheared. It shows several interlocked networks of microfractures (fluid inclusion planes, FIPs) mainly NW-SE and NESW. Cassiterite, as crystals up to $300 \mu \mathrm{m}$ in size, often with Sb traces, and sulphides (pyrite, arsenopyrite, and Co-As-Ni minerals, bismuthinite with Se traces) are found in brecciated QI, 
as well as small disseminated grains (a few $\mu \mathrm{m}$ ) of native Bi (traces of Se and Ag) (Fig. 7a).

269 The coarse-grained white quartz QII is locally associated with brecciated tourmaline agglomerations and followed by pyrite (Fig. 6c).

Fe-Co-Ni sulpharsenides fill fractures or cavities of the breccia and postdate pyrite and QII. They consist of euhedral arsenopyrite, Fe-(Co)-sulphide (Co-pyrite with around 6 wt \% Co), and small size (few $\mu \mathrm{m}$ ) euhedral crystals of Fe-Co-Ni-sulpharsenides and cobaltite (Fig. 7b). After the breccia stage, chlorite 2 and QIII formed around the breccia fragments. Locally, pyrrhotite is spatially associated with chlorite 2 and quartz QIII. In schist, millimetre size clear quartz (QIII) veins are observed sub- parallely to the QI veins, and are lined by a newly crystallised chlorite 2 (Fig. 6d, 6e). They correspond to the re-opening of the QI vein selvage (Fig. 6e). In these zones, QI-QII quartz crystals present recrystallisation halos or epitaxial clearer growth bands at the contact of chlorite 2 .

Cu-ore stage: quartz breccia and microdiorite are crosscut by millimetre to centimetre-sized fractures, lined by feathery comb quartz, siderite and calcite (Fig. 6f to 6h). The late quartz (QIV) is clear, undeformed, and presents euhedral geodic terminations. It hosts scarce fluid inclusions and fluid inclusion planes (Fig. 6i). Chalcopyrite occurs later than QIV as impregnations of the former breccia and microfracture infillings. It sometimes contains traces of Te, scarce inclusions of Fe-sphalerite (up to $8 \mathrm{wt} \% \mathrm{Fe}$ ), stannite as well as an unidentified Bi-Te-Se-S mineral (Fig. 7c, 7d and 7e). Galena is found sporadically in microfractures affecting earlier Fe-As minerals (Fig. $7 \mathrm{~b}$ and 7f). Selenium rich-galena (up to 3 wt $\%$ Se; traces of Bi) locally crosscuts chalcopyrite (Fig. 7g). Precious metals are present as late Ag-Au alloys ( $\mathrm{Ag} / \mathrm{Au}$ around 2).

Supergene alteration: supergene minerals replace sulphides and impregnate breccia fragments and microfractures (Fig. 6c, 6d, and 7h). Thus, exploited copper ores are mostly malachite (Fig. $7 \mathrm{c}, 7 \mathrm{e}$, and $7 \mathrm{~g}$ ) that results from the weathering of chalcopyrite from the $\mathrm{Cu}$-ore stage. $\mathrm{Fe}-$ 
oxides/hydroxides are predominant and are accompanied by a few grains of covellite and cerussite. Native metals $(\mathrm{Pb}, \mathrm{Zn}, \mathrm{Ag}, \mathrm{Cu}, \mathrm{Bi}, \mathrm{Se})$ are present as minute grains (10 to $30 \mu \mathrm{m})$.

\section{Fluid inclusion study}

Fluid inclusions (FIs) were studied in quartz and carbonate from the mineralised breccia as well as in most fracture quartz infillings in the Jbel Haïmer area. Fluid inclusions types are defined in Table 2. Table 3 provides microthermometric data and Table 4 Raman data.

\section{Pre-ore stage}

Fluids in tourmaline: primary FIs are two-phase and water dominated with traces of a lowdensity volatile, noted Lw-(c)-tur (Table 3). Their salinity is estimated around $24-26 \mathrm{wt} \%$ $\mathrm{NaCl}$ equiv. Th, to the liquid phase, ranges between 370 and $390^{\circ} \mathrm{C}$. Secondary FIs in quartz from tourmalinised quartzite are two-phase water dominated FIs with traces of low-density volatile (Lw-(c)1), salinity ranging between 15.7 to $16.5 \mathrm{wt} \% \mathrm{NaCl}$ equiv. and $\mathrm{Th}$ from $286^{\circ} \mathrm{C}$ to above $386^{\circ} \mathrm{C}$ to the liquid phase.

Fluids in early quartz Q1 - biotite/chlorite 1 stage: quartz QI in NW-SE veins and quartz fragments in breccia contain dense clouds of FIs (Fig. 8a) where true primary FIs cannot be easily distinguished. Two types of FIs distribute randomly in QI crystals: i) water dominated FIs with traces of volatiles (Lw1), which are abundant in FIs clouds, have a salinity ranging from 20 to $26 \mathrm{wt} \% \mathrm{NaCl}+\mathrm{CaCl}_{2}$ equiv. and $\mathrm{Th}$ from $296^{\circ}$ to over $357^{\circ} \mathrm{C}$ to the liquid, some of them decrepitating at temperatures above $350^{\circ} \mathrm{C}$; ii) one-phase dense carbonic liquid inclusions, $\mathrm{Lc} 1$, found dispersed in QI show $\mathrm{Tm} \mathrm{CO}_{2}$ from -78.4 to $-67.9^{\circ} \mathrm{C}$, indicative of the presence of significant amounts of other volatiles. $\mathrm{Th}^{\mathrm{CO}} \mathrm{CO}_{2}$ to the liquid phase ranges from -70.2 to $-13.7^{\circ} \mathrm{C}$ with a mode at $-32^{\circ} \mathrm{C}$ (Table 3 ).

Lw2 aqueous FIs containing relatively high vapour infilling (up to 30\%), with small amounts of gas (low density of the volatile phase), are abundant as regular networks of FIPs crosscutting 
QI quartz crystals from veins and breccia. The average salinity ranges from 11.8 to 15.8 wt \% $\mathrm{NaCl}$ equiv. and $\mathrm{Th}$ ranges from 261 to $317^{\circ} \mathrm{C}$ (Table 3).

Fluids in quartz QII (NS to NE-SW white quartz veins): scattered one-phase carbonic vapours (Vc2) and two-phase aqueous carbonic FIs (Lc-w2) coexist in the same QII microdomains (Fig. 8b, 8c). In both FI types, $\mathrm{Tm} \mathrm{CO}_{2}$ ranges from -102.8 to $-68.5^{\circ} \mathrm{C}$ and $\mathrm{Th}^{\mathrm{CO}_{2}}$ from -71.6 to $60.5^{\circ} \mathrm{C}$ to the vapour phase (Table 3$)$. The volatile phase is dominated by $\mathrm{N}_{2}(60-70 \mathrm{~mol} \%)$, (Table 4). Tm cl and Tm ice for Lc-w2 are respectively from -4.2 to $1^{\circ} \mathrm{C}$ and from -8.4 to $3.8^{\circ} \mathrm{C}$. Th of Lc-w2 FIs are recorded over $460^{\circ} \mathrm{C}$ to the liquid phase, but most of the FIs decrepitate around $350^{\circ} \mathrm{C}$. In QII veins, one-phase carbonic vapours (Vc2) and two-phase aqueous-carbonic inclusions (Lc-w2) coexist in the clear quartz microdomains surrounding pyrite. $\mathrm{Vc} 2$ show $\mathrm{Tm} \mathrm{CO}_{2}$ around $-102^{\circ} \mathrm{C}$ and $\mathrm{Th} \mathrm{CO}_{2}$ around $-97^{\circ} \mathrm{C}$ while $\mathrm{Lc}-\mathrm{w} 2$ recorded Tm ice around -10 to $-9^{\circ} \mathrm{C}$, Tm cl from 6.2 to $9.1^{\circ} \mathrm{C}$ and $\mathrm{Th}$ from 414 to $453^{\circ} \mathrm{C}$ to the liquid. Raman spectroscopy analyses show that the volatile phase of Lc-w2 FIs in recrystallised QII is dominated by $\mathrm{CH}_{4}(60-70 \%$ mol\%), (Table 4).

Vapour FIs showing roughly similar microthermometric characteristics to $\mathrm{Vc} 2\left(\mathrm{Tm} \mathrm{CO}_{2}\right.$ modes at $-85^{\circ} \mathrm{C}$ and $-65^{\circ} \mathrm{C}$ and $\mathrm{Th} \mathrm{CO}_{2}$ at -65 to $-60^{\circ} \mathrm{C}$ to the vapour) are present as FIPs crosscutting QI. They are random FIs in recrystallised QI.

Fluids in quartz from breccia and NW-SE QIII - chlorite 2 veinlets: carbonic liquids (Lc3) (Fig. 8d to $8 \mathrm{~h}$ ) are monophase FIs scattered and pseudo-secondary in clear quartz QIII surrounding chlorite 2 crystals and in QIII from veins (Fig. 9). Lc3 form also sets of FIPs parallel to vein walls in QI (Fig. 8d and 8e) and crosscutting QII. Tm $\mathrm{CO}_{2}$ ranges from -65 to $-57.6^{\circ} \mathrm{C}$, and Th $\mathrm{CO}_{2}$ goes from -46.9 to $18.6^{\circ} \mathrm{C}$ to the liquid phase (Table 3). The Lc3 FIs pseudo-secondary in QIII (Fig. 8h) display a $\mathrm{Tm} \mathrm{CO}_{2}$ close to those of pure $\mathrm{CO}_{2}\left(\mathrm{Tm}\right.$ of pure $\mathrm{CO}_{2}$ : $\left.-56.6^{\circ} \mathrm{C}\right)$ and $\mathrm{Th}$ $\mathrm{CO}_{2}$ close or above $0^{\circ} \mathrm{C} . \mathrm{CO}_{2}$ dominates Lc3 FIs (59 to $88 \mathrm{~mol} \%$ ), followed by $\mathrm{N}_{2}$ (10 to 29 mol\%) with lower $\mathrm{CH}_{4}$ content (2 to $14 \mathrm{~mol} \%$ ) (Table 4, Fig. 9). 


\section{Cu-ore stage fluids}

345 Feathery quartz, calcite, and QIV are devoid of carbonic FIs and show exclusively aqueous FIs covering a broad range of salinities. The two major FI types are (Fig. 10, Table 3): i) high salinity FIs with a halite crystal and an unidentified clear solid (noted Lwh), and sometimes a few additional solids (Lws) and ii) moderate to low salinity FIs (Lw) (Fig. 10, Table 3). Chalcopyrite is present in the same quartz microdomains as Lwh brines as well as within Lw FI assemblages from clear quartz QIV microdomains.

Almost all of the aqueous FIs present relatively low eutectic temperatures $\left(-65^{\circ} \mathrm{C}\right)$, likely corresponding to metastable eutectic of the $\mathrm{H}_{2} \mathrm{O}-\mathrm{NaCl}-\mathrm{CaCl}_{2}$ system (Davis et al., 1990). These FIs are present as FIPs in early quartz (QI, QII, and QIII).

High salinity brines: Lws FIs have an irregular shape (Fig. 10a to 10c), and distribute in recrystallised microdomains of quartz QI-QII from veins and breccia, as well as irregular FIPs crosscutting QI, QII, and QIII (Fig. 8g). Salinity is around 38 - $39 \mathrm{wt} \% \mathrm{NaCl}+\mathrm{CaCl}_{2}$ equiv. Most Lws FIs decrepitate upon heating at temperature from $230^{\circ} \mathrm{C}$ with an average decrepitation temperature of $300-330^{\circ} \mathrm{C}$. A few Th were recorded between 174 and $252^{\circ} \mathrm{C}$ to the liquid phase. The dissolution of solids occurs from 90 to $360^{\circ} \mathrm{C}$, mostly at a temperature higher than Th.

Lwh FIs present regular shape and sometimes one unidentified rounded or rhombic-shape clear solid in addition to the halite cube (Fig. $10 \mathrm{~d}$ and $10 \mathrm{~g}$ ), and occasionally a small opaque solid. Lwh FIs are scattered in QIV and form abundant FIPs crosscutting QI, QII, and QIII veins and previous volatile-rich FIPs (Fig. 10e). Besides, Lws and Lwh FIs are sometimes present in the same recrystallised early quartz microdomains where Lwh FIPs often crosscut Lws FIPs. Salinity ranges from 31.3 to $37.3 \mathrm{wt} \% \mathrm{NaCl}+\mathrm{CaCl}_{2}$ equiv. (average $34 \mathrm{wt} \% \mathrm{NaCl}+\mathrm{CaCl}_{2}$ equiv.). Th ranges from 179 to $264^{\circ} \mathrm{C}$ (mode around $220^{\circ} \mathrm{C}$ ), and halite cube melts at 
temperatures ranging from 155 to $262^{\circ} \mathrm{C}$, the second solid remaining unmelted. Some FIs have decrepitated around $270^{\circ} \mathrm{C}$. For most Lwh FIs, $\mathrm{Tm} \mathrm{NaCl}$ and $\mathrm{Th}$ occur roughly in the same average domain between 220 and $230^{\circ} \mathrm{C}$.

Lw FIs in feathery quartz and calcite show Tm ice from -32 (primary in calcite) to $-20^{\circ} \mathrm{C}$ (secondary in feathery quartz and calcite) and Th from 186 to $242^{\circ} \mathrm{C}$. Salinity ranges from 22.4 wt $\%$ to $>30 \mathrm{wt} \% \mathrm{NaCl}$ equiv.

High to low salinity fluids: several types of two-phase aqueous FIs (Lw), sometimes with an unidentified clear solid and sporadically an opaque solid, form regular networks of FIPs in QI, QII, QIII and QIV (Fig. 10g and 10h). Most aqueous FIs show a regular shape and have a vapour infilling around $10 \%$. Tm ice range from -29.6 to $-7.1^{\circ} \mathrm{C}, \mathrm{Tm}$ hh range between -11.9 and $-6.5^{\circ} \mathrm{C}$ and $\mathrm{Th}$ range from 139 to $249^{\circ} \mathrm{C}$ with several modes corresponding to different FIPs. Salinities range from 10.6 to $28 \mathrm{wt} \% \mathrm{NaCl}+\mathrm{CaCl}_{2}$ equiv. Clear solids do not melt until temperatures over $330^{\circ} \mathrm{C}$. FIs in planes crosscutting QIV crystals show salinities from 9 to 15.3 wt $\% \mathrm{NaCl}$ equiv. and Th from 156 to $242^{\circ} \mathrm{C}$. Scarce FIs, scattered in the recrystallised quartz around chalcopyrite (Fig. 10f), have a salinity around $23 \mathrm{wt} \% \mathrm{NaCl}$ equiv. and Th around 150$160^{\circ} \mathrm{C}$

A general trend corresponds to a decrease in salinity at constant or slightly decreasing Th from the Lws brine to Lw FIs (Fig. 11). The salinity evolution is in agreement with chronological relationships between aqueous fluid inclusion types that start with Lws, crosscut by Lwh FIPs, and both of them being crosscut by several Lw FIPs that show a gradual decrease in salinity. The latest Lw FIs that crosscut quartz QIV present the lowest salinities (Fig. 11). Chalcopyrite deposition occurred when mixing occurred, e.g. when fluids were characterised by intermediate features between the two end-members of this general trend (i.e., Lws and Lw FIPs in QIV).

Major elements and metal content of the brine inclusions: LA-ICP-MS data for Lws and Lwh brines are given in Table 5 and Fig. 12. Lw fluid inclusions were too small to be analysed. 
Lws brines (FIPs in QI, QII and QIII) show relatively high Na content (average $2735 \mathrm{mmol} / \mathrm{kg}$ ), $\mathrm{Ca}$, and $\mathrm{K}$, (average around $941 \mathrm{mmol} / \mathrm{kg}$, and $397 \mathrm{~mol} / \mathrm{kg}$ respectively) but low Mg content (73 $\mathrm{mmol} / \mathrm{kg}$ ) (Table 5, Table 6). Average molar $\mathrm{Na} / \mathrm{Ca}, \mathrm{Na} / \mathrm{K}$, and $\mathrm{Na} / \mathrm{Mg}$ ratios are 2.9, 6.9, and 37.7, respectively. Lws FIs display $\mathrm{Pb}$ and $\mathrm{Zn}$ contents of $72.2 \mathrm{mmol} / \mathrm{kg}$ and $159.1 \mathrm{mmol} / \mathrm{kg}$ respectively on average and a $\mathrm{Cu}$ content of $19.1 \mathrm{mmol} / \mathrm{kg}$. $\mathrm{Ag}$ concentration is around 0.2 $\mathrm{mmol} / \mathrm{kg}$ (Table 5, Table 6).

Lwh FIs (quartz QIV): in Lwh FIs, Na is also the dominant cation (average around 1532 $\mathrm{mmol} / \mathrm{kg})$, but they are rich in $\mathrm{Ca}(1174 \mathrm{mmol} / \mathrm{kg}), \mathrm{K}$ and $\mathrm{Mg}(580 \mathrm{mmol} / \mathrm{kg}$ and $501 \mathrm{mmol} / \mathrm{kg}$, respectively) (Table 5, Table 6). The average molar ratios are around 1.3 for $\mathrm{Na} / \mathrm{Ca}, 2.6$ for $\mathrm{Na} / \mathrm{K}$ and 3.1 for $\mathrm{Na} / \mathrm{Mg}$. High amounts of $\mathrm{Pb}, \mathrm{Zn}$ and especially $\mathrm{Cu}$ are present in Lwh brines (average: $28.8 \mathrm{mmol} / \mathrm{kg}, 136.8 \mathrm{mmol} / \mathrm{kg}$ and $43.9 \mathrm{mmol} / \mathrm{kg}$ respectively) as well as $\mathrm{Ag}$ (average. $5.3 \mathrm{mmol} / \mathrm{kg}$ ) (Table5, Table 6). In Lwh brines, $\mathrm{Cu}$ and $\mathrm{Pb}$ concentrations are correlated with $\mathrm{Na}$. Fe is detected at high concentrations, and is certainly present. Fe contributions were however not considered in the calculations because of probable contaminations by solids yielding unrealistic contents.

From Lws to Lwh brines, $\mathrm{K}, \mathrm{Ca}, \mathrm{Mg}, \mathrm{Cu}$, As and $\mathrm{Ag}$ concentrations increase, together with a decrease in $\mathrm{Na}, \mathrm{Zn}, \mathrm{Pb}, \mathrm{Ba}, \mathrm{Rb}$, and $\mathrm{Sr}$ concentrations (Fig. 12, 13). Similar positive correlations are obtained for $\mathrm{Sr}-\mathrm{Ba}$, and $\mathrm{As}-\mathrm{Cu}$. By comparison, brines from Jbel Haïmer contain higher $\mathrm{Zn}, \mathrm{Cu}, \mathrm{Pb}$ and $\mathrm{Ag}$ contents than those from the Roc Blanc deposit (Essarraj et al., 2017a), (Table 6 and Fig. 13). The high chlorinity, the richness in $\mathrm{K}, \mathrm{Ca}$ and $\mathrm{Mg}$ are typical of evaporitic brines as discussed below (Fig. 14).

\section{Discussion}

\section{Pre-ore stage fluids in the regional metamorphic context}

Early tourmaline-biotite-Sn assemblage: Tourmaline formed first from hot brines (around 25 
$\mathrm{wt} \% \mathrm{NaCl}$ equiv., $\mathrm{T}>380^{\circ} \mathrm{C}$ ) related to granitoid intrusions, which produced hornfels in the contact metamorphic aureole where tourmaline-rich pegmatite veins and lenses are abundant.

C-H-O-N fluids: NW-SE-striking fractures with quartz QI (biotite) infillings followed by NESW fractures with quartz QII, formed from $\mathrm{N}_{2}-\mathrm{CH}_{4}-\left(\mathrm{CO}_{2}-\mathrm{H}_{2} \mathrm{O}\right)$ fluids at a temperature ranging from 450 to $500^{\circ} \mathrm{C}$. Brecciation occurred in the competent NE-SW sandy schist and sandstonequartzite layers later than QI, QII veins and is synchronous with new NW-SE fractures likely conjugated with NE-SW fractures. Large circulation of $\mathrm{CO}_{2}-\left(\mathrm{H}_{2} \mathrm{O}\right)$ dominated fluid produced the cementation of the breccia and newly formed NW-SE fractures filled with quartz QIII and chlorite 2.

An evolution in the volatile phase composition (Fig. 9) occurred from $\mathrm{N}_{2}-\mathrm{CH}_{4}\left( \pm \mathrm{H}_{2} \mathrm{O}\right)$ rich fluid associated with early quartz (QI, QII) towards $\mathrm{CH}_{4}-\mathrm{CO}_{2}\left( \pm \mathrm{H}_{2} \mathrm{O}\right)$ rich fluid associated with pyrite deposition. Finally, $\mathrm{CO}_{2}$-rich fluid associated with chlorite 2 deposition ends the volatilerich fluid series. Aqueous-carbonic fluids $\left(\mathrm{N}_{2}-\mathrm{CH}_{4}-\left(\mathrm{CO}_{2} \pm \mathrm{H}_{2} \mathrm{O}\right)\right)$ from Jbel Haïmer are very similar to those observed in the Roc Blanc and Koudia El Hamra silver-(base metal) deposits (Essarraj et al., 2017a; Nshimiyimana et al., 2018, respectively) (Fig. 9). Bastoul (1992) documented fluids with similar volatile composition in skarns located a few kilometres North of Jbel Haïmer (Fig. 9). Most volatile-rich fluids were produced during the HT-LP M2a stage under regional metamorphism conditions $\left(500-650^{\circ} \mathrm{C}\right.$ and $\left.200 \mathrm{MPa} \pm 20 \mathrm{MPa}\right)$ (Bastoul, 1992; Delchini et al., 2018). The production of $\mathrm{H}_{2} \mathrm{O}-\mathrm{CO}_{2}-\mathrm{CH}_{4}$ rich fluids in this $\mathrm{P}-\mathrm{T}$ range results typically from water and graphite equilibrium under reduced conditions close to Q-F-M buffer which constitutes a rather good proxy of the redox conditions in metamorphic series (Huizenga, 2001; Huff and Nabelek, 2007). Additional local sources are needed to explain the mixing trends among volatiles: i) a mixing trend between $\mathrm{N}_{2}$ rich fluids and $\mathrm{CH}_{4}$ rich fluids, and ii) a mixing trend between a $\mathrm{CO}_{2}$ rich fluid end-member and the $\mathrm{N}_{2}-\mathrm{CH}_{4}$ mixed fluids. Bastoul (1992) found the same trends and attributed the formation of $\mathrm{N}_{2}$ to the oxidation of $\mathrm{NH}_{4}{ }^{+}$from 
micas as also documented by Wright et al. (2012). Both authors have reported the occurrence of ammonium-rich phyllosilicates in metamorphic series and the related production of $\mathrm{N}_{2}$ during their heating. $\mathrm{N}_{2}-\mathrm{CH}_{4}$ rich fluids are thus produced in graphite-rich series submitted to contact or retrograde metamorphism with highly variable $\mathrm{N}_{2} / \mathrm{CH}_{4}$ ratio and are in general very poor in water.

High thermal gradients: High temperatures recorded by early metamorphic fluids at Jbel Haïmer ( $\mathrm{Th}>450^{\circ} \mathrm{C}$, this study) are in agreement with several temperature estimates: i) those proposed for the Central Jebilet (Bastoul, 1992), and ii) the temperatures derived from the graphite Raman thermometry (based on the structural organisation of the carbonaceous material to graphite) applied to hornfels (475 to $630^{\circ} \mathrm{C}$, Delchini et al., 2016). Isotope data $(\mathrm{O}, \mathrm{H})$ of $\mathrm{N}_{2-}$ $\mathrm{CH}_{4}-\mathrm{CO}_{2} \pm \mathrm{H}_{2} \mathrm{O}$ fluids either at the Roc Blanc deposit ( $\delta^{18} \mathrm{O}$ of waters in equilibrium with early quartz: 12.6 - 14.0\%o v-smow; $\delta$ D: -43.2 to $-37.1 \%$ v-smow, Essarraj et al., 2017a) or the Kettara deposit $\left(\delta^{18} \mathrm{O}\right.$ of waters in equilibrium with chlorite: 6.0 to $7.2 \%$ v-SMOw; $\delta \mathrm{D}:-14.5$ to $-10.5 \%$, N'Diaye et al., 2016), compared to the composition of metamorphic waters from Sheppard (1986) confirm their metamorphic origin. Whatever their pristine source, a significant part of the described waters deeply equilibrated with metamorphic series, in particular with graphite producing $\mathrm{H}_{2} \mathrm{O}-\mathrm{CO}_{2}-\mathrm{CH}_{4}$ fluids. Early metal extraction and transport (Fe, $\left.\mathrm{Sn}, \mathrm{As}, \mathrm{Bi}, \mathrm{Co}, \mathrm{Ni}\right)$ at Jbel Haïmer were probably favoured at that stage by aqueous-carbonic fluids set in motion in close connection with the HT-LP thermal metamorphism (M2a) and the late granites

462 intruding the Sarhlef series (M2b). Aqueous-carbonic fluids play a significant role in metal transport and deposit in a great variety of Variscan deposits (Wilkinson et al., 1990; Cathelineau et al., 2020). $\mathrm{N}_{2}$-rich fluids may be the main ore fluids in scheelite deposits (Wang et al., 2018) and $\mathrm{CH}_{4}$-rich fluids in $\mathrm{C}$-rich formations close to Au-As deposits (Guedes et al., 2002; Boiron et al., 2003). 
P-T evolution: the pressure and temperature of trapping were estimated using isochores for most fluid types (Fig. 15A). The earliest fluids, Lw-(c)-tur FIs in tourmaline, were trapped at conditions close or slightly below those estimated for the thermal metamorphism (M2a). A significant temperature increase of approximately $250-300^{\circ} \mathrm{C}$ was therefore reached from regional metamorphic conditions, leading to thermal gradients of around $70^{\circ} \mathrm{C} / \mathrm{km}(\mathrm{P}-\mathrm{T}$ box from Bastoul, 1992, Fig. 15A). Their isochores crosscut the P-T box for the HT-LP metamorphic conditions, which constitutes the maximal estimate. Isochores for the earliest FIs in quartz QI (Lw1) are subparallel to those of tourmaline FIs, while Lc1 isochores define a broad pressure range in between 70 and $150 \mathrm{MPa}$. Both fluids are considered as subsynchronous. The intersection of their isochores provides an estimated pressure range of 70 to $150 \mathrm{MPa}$, and temperatures ranging from 360 to $460^{\circ} \mathrm{C}$. For the second stage of quartz QII, consideration of the assemblage Lc-w2 and Vc2 yield to the following P-T estimate: 70-110 $\mathrm{MPa}, 450-520^{\circ} \mathrm{C}$. The values are close to those of unmixing defined by the isopleths in the $\mathrm{H}_{2} \mathrm{O}-$ $\mathrm{CO}_{2}-\mathrm{NaCl}$ system for two different $\mathrm{CO}_{2}$ contents. Such a process can explain the presence of Vc2 fluids. The third stage QIII is characterised by carbonic liquids that do not provide strong constraints on their trapping P-T box except the temperature estimate for the chlorite (300$350^{\circ} \mathrm{C}$ ), which are similar to those of the Roc Blanc deposit. Carbonic liquids are thus trapped under higher pressure than in the preceding stage, in between 120 and $170 \mathrm{MPa}$.

The evolution of fluids from the tourmaline stage to QI and QII suggests a significant pressure decrease from lithostatic conditions towards hydrostatic conditions, in agreement with the pressure release expected after the breccia formation. During stage QIII, pressure increased again up to values close to those of the lithostatic regime. In both cases, the P-T box is intersected by a thermal gradient of around 60 and $70^{\circ} \mathrm{C} / \mathrm{km}$ indicative of high thermal gradients in agreement with the thermal metamorphism and late intrusions of magmatic bodies defined by Delchini et al. (2018). 
Most fluids from the early stages are therefore related to both abnormal thermal fluxes linked to HT-LP metamorphism and late granite magmatism during deformation stage D2. The presence of drainage zone, such as the MSZ and the Aït Bella OuSaïd shear zone, favoured collect and mixing of the different types of volatile-rich fluids generated during the thermal event (Fig. 16A). Fluids under lithostatic pressure may have produced brecciation and subsequent fluid decompression and precipitation of quartz QIII.

\section{Cu brine circulation during post Variscan events in the Jebilet massif}

$P-T$ conditions: the intersection between the isochores calculated for the three FI types (Lws, Lwh, and Lw), and the thermal gradients expected in basins during extensional stages linked to rifting (see discussion below), provides an estimate P-T pair of $40-50 \mathrm{MPa}$ and $220-280^{\circ} \mathrm{C}$ (Fig. 15B). Considering hydrostatic conditions and abnormal thermal gradient of $40^{\circ} \mathrm{C} / \mathrm{km}$ and $50^{\circ} \mathrm{C} / \mathrm{km}$ during this particular period, pressures correspond to a depth of around 4 to $5 \mathrm{~km}$. Such a depth comprises the thickness of the Mesozoic series in the Jebilet (up to $2.4 \mathrm{~km}$ ), and therefore yield to an estimate of the depth below the unconformity of 1.6 to $2.6 \mathrm{~km}$.

Triassic formations as brine source: The Jbel Haïmer brines are characterised by high salinities from 31 to $37 \mathrm{wt} \% \mathrm{NaCl}+\mathrm{CaCl}_{2}$ equiv. (average $34 \mathrm{wt} \% \mathrm{NaCl}+\mathrm{CaCl}_{2}$ equiv.), are trapped around $220-280^{\circ} \mathrm{C}$, and are enriched in $\mathrm{K}, \mathrm{Mg}$ and $\mathrm{Ca}$. They are similar to those of the Roc Blanc Ag-deposit (20 wt $\%$ to $35 \mathrm{wt} \% \mathrm{NaCl}$ equiv., trapping temperature around $200^{\circ} \mathrm{C}$ and pressure of $50 \mathrm{MPa}$, Essarraj et al., 2017a) and the Koudia El Hamra Ag-deposit (Nshimiyimana et al., 2018).

The major element contents of the two brines Lwh and Lws were compared to those of seawater and evaporated seawater after the halite saturation. The high chlorinity, the richness in $\mathrm{K}$ (and $\mathrm{Mg}$ ) are typical of brines having passed halite saturation (Fontes and Matray, 1993) (Fig. 14). 
basins or in basement faults (Poitou high (France): Boiron et al., 2002; Black Forest (Germany): Walter et al., 2019; Catalan coastal range (NE Spain): Piqué et al., 2018). The calcium enrichment, common to fluids from all sites, is generally interpreted as the result of water-rock interactions such as albitisation (Black Forest, Walter et al., 2016), and the relatively broad range of $\mathrm{Mg}$ contents as the result of $\mathrm{Mg}$ uptake by the crystallisation of dolomite in the sedimentary cover, and talc or other Mg silicates in the basement (Trimouns (Pyrénées, France): Leisen et al., 2012b).

Evaporites within the sedimentary clastic sequences, up to $8 \mathrm{~km}$ thick, from Atlasic basins, constitute good candidates for the source of brines. These subsident basins formed in relation with the Early Triassic to Early Jurassic extension stages (Studer, 1987; Warme, 1988), and constituted the High Atlas Belt. In the Central Jebilet, Triassic evaporite series outcrop a few kilometres South-East of Jbel Haïmer (Fig. 2a), and layers with sufficient thickness to be mined, about $100 \mathrm{~km}$ West of Jbel Haïmer in the Western Jebilet. The basement, now stripped of its Mesozoic cover as a result of erosion, was most probably continuously covered by Triassic evaporites during the Mesozoic.

Metal concentrations in brines: brines have high concentrations in $\mathrm{Cu}, \mathrm{Pb}, \mathrm{Zn}$, (and $\mathrm{Ag}$ for Lwh) which were probably extracted from basement rocks (Fig. 16B). Among other potential source rocks present in the region, the black shales may release Ag, As, basic intrusions and some VMS lenses, $\mathrm{Cu}$ and $\mathrm{Zn}$. These lithologies (metal sources) occur as weathered rocks just below the Triassic formations (brine source). Regoliths are generally considered as reserves of easily extractible metals by brines coming for upper levels (Boiron et al., 2010; Cathelineau and Boiron, 2019). Base metal contents in brines (Cu, Pb, Zn) are higher at Jbel Haïmer than at Roc Blanc (Table 6). Brines transported, therefore, specific metal contents depending on the deposit. 
Mechanisms of Cu-ore deposition: metals might have been transported as chloride complexes owing to the high salinity of brines and the high $\mathrm{Cu}, \mathrm{Zn}$, and $\mathrm{Pb}$ of the Lwh brine (Yardley, 2005; Wilkinson et al., 2009). Thus, at temperatures below $300^{\circ} \mathrm{C}$, chloride complexes are the predominant $\mathrm{Cu}, \mathrm{Pb}$, and $\mathrm{Zn}$ species, whereas hydrosulphides predominate at a higher temperature $\left(>400^{\circ} \mathrm{C}\right)$ in sulphide-saturated systems (Zhong et al., 2015).

Tm ice - Th pairs distribute between two end-members, the Lws and Lwh brines on the one hand, and a low salinity water end-member ( $\mathrm{Lw}$ ) on the other hand (Fig. 11). This trend corresponds to mixing between brine and a low-salinity fluid. The mixing is synchronous with the chalcopyrite deposition. The chlorinity decrease due to mixing may have destabilised metal ( $\mathrm{Zn}, \mathrm{Cu}, \mathrm{Pb}$ ) chloride complexes, and caused metal deposition (Wilkinson, 2001; Heijlen et al., 2003; Boiron et al., 2002, 2010; Neiva et al., 2015; Richard et al., 2016).

Moreover, Walter et al. (2019) emphasise on the example of the Schwarzwald district (SW Germany) that base metal (sulphide) ores form only if fluid mixing and sulfate reduction occur at the same time, TSR being the main process reducing sulfates from Triassic evaporites to produce $\mathrm{H}_{2} \mathrm{~S}$. For those authors, a reducing agent (methane, for instance, or graphite in close host rocks) is required to precipitate ores. For example, Heijlen et al. (2008) noticed that the distribution of organic material determines the location of mineralisation in some parts of the Central African copper belt (DR Congo). At Jbel Haïmer, as at several studied areas in the Central Jebilet, graphite is abundant, and gas $\left(\mathrm{CH}_{4}, \mathrm{CO}_{2}\right)$ storage in schist microporosity was documented (Bastoul, 1992). Thus, fluid mixing and reduction are the main factors controlling metal deposit at Jbel Haïmer. Likewise, Essarraj et al. (2017a) and Nshimiyimana et al. (2018) evoked a fluid reduction in graphite-rich black shale as a deposition mechanism for base metal and silver mineralisation at the Roc Blanc and Koudia El Hamra deposits, respectively.

Relative age of Cu-ore deposition: $\mathrm{As} \mathrm{Cu}$ mineralisation at Jbel Haïmer occurs after the intrusion and deformation of the microdiorite dikes dated at $240 \pm 10 \mathrm{Ma}$ (Bouloton et al., 
2019), Triassic brine circulation during Mesozoic is, therefore, the most likely hypothesis. The thermal and tectonic stages related to the Central Atlantic Rifting are the main periods already proposed in a variety of other deposits for such brine migration (Jbel Ighoud barite deposit, Eastern Jebilet: Valenza et al., 2000; Roc Blanc Ag deposit: Essarraj et al., 2017a; Koudia El Hamra Ag deposit: Nshimiyimana et al., 2018). Furthermore, large basaltic flows, coeval with the Central Atlantic Ocean opening are reported in the region (Frizon de Lamotte et al., 2008, 2009). They are witnesses of abnormal thermal gradients recorded in the Western Meseta between 250 and $210 \mathrm{Ma}$ (Ghorbal et al., 2008; Saddiqi et al., 2009; Barbero et al., 2011), and around $195 \pm 4$ Ma (Huon et al., 1993).

At Jbel Haïmer, tectonic traps consist of clusters of reactivated and re-opened Variscan (N-S to NE-SW and NW-SE) discontinuities during post-Variscan events. The nearby presence of the MSZ and the Aït Bella OuSaïd shear zone may constitute drainage zones for brines (Fig. 2a and 16B), as they are reactivated during the Central Atlantic rifting (Laville and Piqué, 1991; Piqué and Laville, 1993, 1996).

Similar ore deposition processes in Morocco: Early fluid stages synchronous with the Panafrican magmatism and metamorphism, followed by later migration of evaporitic brines during the Mesozoic are typical of most Anti-Atlas deposits: Zgounder (Ag-Hg), Bou Azzer (Co-Ni-Ag-Au), and Imiter (Ag-Hg) deposits (Essarraj et al., 1998, 2005, 2016, 2017b). Similarly, fluid flows induced by extensional tectonics, contemporary with the first stages of the Atlantic Ocean opening, are proposed for the Assif El Mal deposit, High Moulouya district and Tirhza-Jbel Aouam district (base metal - polymetallic, Morocco) (Bouabdellah et al., 2009; Margoum et al., 2015; Rossi et al., 2016 respectively).

\section{Conclusion}


590

591

This study concludes a general framework of fluid circulations and mineral deposition at the Jbel Haïmer area summarised as follows:

592

- The first stage is related to fluid convection induced by Late Variscan magmatism. High-temperature fluids having a typical metamorphic signature (C-O-N-H) deposited minor concentrations of Sn-As-(Co-Ni) in quartz veins.

- The second stage occurs much later and is independent of the first stage. It is characterised by the introduction of metals $(\mathrm{Cu}-(\mathrm{Zn}-\mathrm{Pb}), \mathrm{Ag})$ in the system by primary evaporitic brines characterised by their salinity and enrichment in $\mathrm{K}, \mathrm{Mg}$. The likely origin of the brines is the Triassic evaporitic levels deposited above the basement unconformity. The high metal concentrations in fluid inclusions are considered as an excellent pathfinder of exploration targets. The high chlorinity of the brines favoured the extraction of metals from basement rocks, especially those affected by weathering (regolith) located just below the unconformity and Triassic formations.

- $\mathrm{Cu}$-ores deposited at medium temperatures $\left(220-280^{\circ} \mathrm{C}\right)$ corresponding to a burial of around 4-5 km. The main driving force for $\mathrm{Cu}$-deposition is the dilution of ore-forming brines by low salinity fluids, probably of meteoric origin.

- Tectonic traps are issued in part from Variscan deformation which developed damaged zone along shear zones. Mesozoïc extensional tectonics reactivated inherited shear zones during post-240 Ma events. Although the absolute age of the $\mathrm{Cu}$-ore stage is not available, it is likely related to the Atlantic Ocean rifting stages. The latter favoured the downward migration of Triassic brines into the basement. Such processes are very similar to those proposed for the Anti-Atlas, High Atlas and Meseta silver and base metal deposits. 
618 M. Hibti, K. El Amari, and A. Saïdi are warmly acknowledged for their help during field works. 619 The LA-ICP-MS laboratory from GeoRessources was funded by the Lorraine region, the 620 European Community through the FEDER program, and by the French National Research 621 Agency through the national program "Investissements d'Avenir" of the Labex Ressources21 622 with the reference ANR-10-LABX-21-RESSOURCES21. The comments and valuable 623 suggestions of A. van den Kerkhof and an anonymous reviewer significantly helped to improve 624 the manuscript. We would like to thank B. Zoheir, the associate editor and F. Pijarno, the editor 625 of Ore Geology Reviews, for valuable comments and editorial handling.

626

627

628

629

630

631 


\section{References}

633

634

635

636

637

638

639

640

641

642

643

644

645

646

647

648

649

650

651

652

653

654

655

656

657

658

659

660

661

662

663

Aarab, E., Beauchamp, J., 1987. Le magmatisme carbonifère préorogénique des Jebilet centrales (Maroc). Précisions pétrographiques et sédimentaires. Implications géodynamiques. Comptes Rendus Académie des Sciences Paris (Série II) 304, 169-175.

Bakker, R.J., 1997. CLATHRATES: Computer programs to calculate fluid inclusion: V-X. Properties using clathrate melting temperatures. Computer Geosciences 23, 1-18.

Bakker, R.J., 2003. Package FLUIDS 1. Computer programs for analysis of fluid inclusion data and for modelling bulk fluid properties. Chemical Geology 194, 3-23.

Bamoumen, H., Olivier, P., 2007. The Oulad Ouaslam Variscan granitic pluton (Jebilets Massif, Southwestern Moroccan Meseta): A forcibly emplaced laccolithic intrusion characterised by its magnetic and magmatic fabrics. Journal of African Earth Sciences 47, 1, 49-61.

Barbero L., Jabaloy, A., Gómez-Ortiz, D., Pérez-Peña, J.V., Rodríguez-Peces, M.J., Tejero, R., Estupiñan, J., Azdimousa, A., Vázquez, M., Asebriy, L., 2011. Evidence for surface uplift of the Atlas Mountains and the surrounding peripheral plateaux: Combining apatite fissiontrack results and geomorphic indicators in the Western Moroccan Meseta (coastal Variscan Paleozoic basement). Tectonophysics 502, 90-104.

Bastoul, A., 1992. Origine et évolution des fluides hydro-carbo-azotés dans les formations métamorphiques: relations avec les minéralisations associées (U, Au, graphite). Unpublished $\mathrm{PhD}$ thesis, University of Nancy, France (311 pp.).

Beauchamp, J., 1984. Le Carbonifère inférieur des Jebilet et de l'Atlas de Marrakech (Maroc): Migration et comblement d'un bassin marin. Bulletin Société Géologique de France 7, 10251032.

Beauchamp, J., Izart, A., Piqué, A., 1991. Les bassins d'avant-pays de la chaîne hercynienne au Carbonifère inférieur. Canadian Journal of Earth Sciences 28, 2024-2041.

Bernard, A.J., Maier, O.W., Mellal, A., 1988. Aperçu sur les amas sulfurés massifs des hercynides marocaines. Mineralium Deposita 23, 104-114.

Bodnar, R.J., Vityk, M.O., 1994. Interpretation of microthermometric data for $\mathrm{H}_{2} \mathrm{O}-\mathrm{NaCl}$ fluid inclusions. In: Fluid Inclusions in Minerals, Methods and Applications, B. De Vivo and M. L. Frezzotti, eds, pub. Virginia Tech, Blacksburg, 117-130.

Boiron, M.C., Essarraj, S., Sellier, E., Cathelineau, M., Lespinasse, M., Poty, B., 1992. Identification of fluid inclusions in relation to their host microstructural domains in quartz by cathodoluminescence. Geochimica et Cosmochimica Acta 56, 175-185. 
Boiron, M.C., Cathelineau, M., Banks, D.A., Buschaert, S., Fourcade, S., Coulibaly, Y., Boyce, A., Michelot, J.L., 2002. Fluid transfers at the basement/cover interface. Part II: Large-scale introduction of chlorine into the basement by Mesozoic brines. Chemical Geology 192, 121140.

Boiron, M.C., Cathelineau, M., Banks, D.A., Fourcade, S., Vallance, J. 2003. Mixing of metamorphic and surficial fluids during the uplift of the Hercynian upper crust: consequences for gold deposition. Chemical Geology 194, 119-142.

Boiron, M.C., Cathelineau, M., Richard, A., 2010. Fluid flows and metal deposition near basement/cover unconformity: lessons and analogies from $\mathrm{Pb}-\mathrm{Zn}-\mathrm{F}-\mathrm{Ba}$ systems for the understanding of Proterozoic U deposits. Geofluids 10, 270-292.

Bordonaro, M., 1983. Tectonique et pétrographie du district à pyrrhotite de Kettara (Paléozoïque des Jebilet, Maroc). Unpublished thesis, Louis Pasteur University, Strasbourg, France (132 pp.).

Bouabdellah, M., Beaudoin, G., Leach, D.L.F., Grandia, F., Cardellach, E., 2009. Genesis of the Assif El Mal $\mathrm{Zn}-\mathrm{Pb}(\mathrm{Cu}, \mathrm{Ag})$ vein deposit. An extension-related Mesozoic vein system in the High Atlas of Morocco. Structural, mineralogical and geochemical evidence. Mineralium Deposita 44, 6, 689-704.

Bouloton, J., Gasquet, D., 1995. Melting and undercooled crystallisation of felsic xenoliths from minor intrusions (Jebilet massif, Morocco). Lithos 35, 201-219.

Bouloton, J., Gasquet, D., Pin C., 2019. Petrogenesis of the Early-Triassic quartz-monzodiorite dikes from Central Jebilet (Moroccan Meseta): Trace element and Nd-Sr isotope constraints on magma sources, and inferences on their geodynamic context. Journal of African Earth Sciences 149, 451-464.

Boutira, M., Hakkou, R., 2012. Cartographie et étude structurale et pétrographique du massif du Jbel Haïmer, Jebilet Centrales- Maroc. Unpublished Internal report, Faculty of Sciences and Technology, Cadi Ayyad University (60 pp.).

Cathelineau, M., Boiron, M.C., 2019. Brine-regolith interactions, a key for metal extraction and re-deposition near unconformities. Basins and Resource Nancy, abstract volume, p. 42.

Cathelineau, M., Boiron, M.C., Marignac, C., Dour, M., Dejean, M., Carocci, E., Truche, L., Pinto, F., 2020. High pressure and temperatures during the early stages of tungsten deposition at Panasqueira revealed by fluid inclusions in topaz. Ore Geology Reviews, 126:103741. DOI: https://doi.org/10.1016/j.oregeorev.2020.103741. 
Davis, D.W., Lowenstein, T.K., Spencer, R.J., 1990. Melting behavior of fluid inclusions in laboratory-grown halite crystals in the systems $\mathrm{NaC} 1-\mathrm{H}_{2} \mathrm{O}, \mathrm{NaCl}-\mathrm{KC} 1-\mathrm{H}_{2} \mathrm{O}, \mathrm{NaCl}-\mathrm{MgCl}_{2}-$ $\mathrm{H}_{2} \mathrm{O}$, and $\mathrm{NaC} 1-\mathrm{CaCl}_{2}-\mathrm{H}_{2} \mathrm{O}$. Geochimica et Cosmochimica Acta 54, 591-601.

Delchini, S., 2018. Etude tectono-thermique d'un segment orogénique varisque à histoire géologique complexe : analyse structurale, géochronologique et thermique du massif des Jebilet, de l'extension à la compression. Unpublished $\mathrm{PhD}$ thesis, University of Orléans, France (233 pp.).

Delchini, S., Lahfid, A., Lacroix, B., Baudin, T., Hoepffner, C., Guerrot, C., Lach, P., Saddiqi, O., Ramboz, C., 2018. The geological evolution of the Variscan Jebilet massif, Morocco, inferred from new structural and geochronological analyses. Tectonics, 37, 12, 4470-493.

Delchini, S., Lahfid, A., Plunder, A., Michard, A., 2016. Applicability of the RSCM geothermometry approach in a complex tectono-metamorphic context: The Jebilet massif case study (Variscan Belt, Morocco). Lithos 256-257, 1-12.

Dostal, J., Keppie, J.D., Hamilton, M.A., Aarab, E.M., Lefort, J.P., Murphy, J.B., 2005. Crustal xenoliths in Triassic lamprophyre dikes in western Morocco: tectonic implications for the Rheic ocean suture. Geological Magazine 142, 159-172.

Dubessy, J., 1984. Simulation des équilibres chimiques dans le système C-O-H, conséquences méthodologiques pour les inclusions fluides. Bulletin de Minéralogie 107, 155-168.

Dubessy, J., Poty, B., Ramboz, C., 1989. Advances in the C-O-H-N-S fluid geochemistry based on micro-Raman spectroscopic analysis of fluid inclusions. European Journal of Mineralogy $1,517-534$.

El Arabi, E.H., 2007. La série permienne et triasique du rift haut-atlasique: nouvelles datations; évolution tectonosédimentaire. Unpublished thesis Hassan II University, Casablanca, Morocco (225 pp.).

El Hassani, A., 1980. Etude lithostratigraphique, tectonique et pétrographique de la région de Sidi Bou-Othmane (Maroc). Contribution à la connaissance de l'évolution du segment hercynien des Jebilets centrales. Unpublished $\mathrm{PhD}$ thesis, University of Aix-Marseille, France (114 pp.).

Essaifi, A., Potrel, A., Capdevila, R., Lagarde, J.L., 2003. U-Pb dating: emplacement age of the bimodal magmatism of Central Jebilet (Variscan Belt, Morocco). Geodynamic implications. Comptes Rendus Geosciences 335, 193-203.

Essarraj, S., Boiron, M.C., Cathelineau, M., Banks, D.A., Benharref, M., 2005. Penetration of surface evaporated brines into the Proterozoic basement and deposition of Co and Ag at Bou 
Azzer (Morocco): evidence from fluid inclusions. Journal of African Earth Sciences 41, 2539.

Essarraj, S., Boiron, M.C., Cathelineau, M., Banks, D.A., El Boukhari, A., Chouhaïdi, M.Y., 1998. Brines related to Ag deposition in the Zgounder silver deposit (Anti-Atlas, Morocco). European Journal of Mineralogy 10, 1201-1214.

Essarraj, S., Boiron, M.C., Cathelineau, M., Tarantola, A., Leisen, M., Boulvais, Ph., Maacha, L., 2016. Basinal brines at the origin of the Imiter Ag-Hg deposit (Anti-Atlas, Morocco): evidence from LA-ICP-MS data on fluid inclusions, halogen signatures and stable Isotopes (H, C, O). Economic Geology 111, 1753-1781.

Essarraj, S., Boiron, M.C., Cathelineau, M., Tarantola, A., Leisen, M., Hibti, M., 2017a. Mineralogy and ore fluid chemistry of the Roc Blanc Ag deposit, Jebilet Variscan massif, Morocco. Journal of African Earth Sciences 127, 175-193.

Essarraj, S., Boiron, M.C., Cathelineau, M., Tarantola, A., Leisen, M., Boulvais, P., 2017b. Basinal brines at the origin of the Imiter Ag-Hg deposit (Anti-Atlas-Morocco): evidence from LA-ICP-MS data on fluid inclusions, Halogen signatures and stable isotopes $(\mathrm{H}, \mathrm{C}, \mathrm{O})$. A reply. Economic Geology 112, 1273-1277.

Essarraj, S., Saïdi, A., Boutira, M., Hakkou, R., Erradnaoui A., 2013. Etude structurale et altérations hydrothermales Autour des filons minéralisés du gite de Jbel Haïmer, Jebilet, Maroc. 8eme Colloque International «Magmatisme, Métamorphisme et Minéralisations Associées », Marrakech, Mai 2013.

Fontes, J.C., Matray, J.M., 1993. Geochemistry and origin of formation brines from the Paris Basin, France. I. Brine associated with Triassic salts. Chemical Geology 109, 149-175.

Frizon de Lamotte, D., Leturmy, P., Missenard, Y., Khomsi, S., Ruiz, G., Saddiqi, O., Michard, A., Charrière, A., 2009. Meso-Cenozoic vertical movements in the Atlas System (Algeria, Morocco, Tunisia): origin of longitudinal asymmetry of topography and rock material - an overview. Tectonophysics 475, 9-28.

Frizon de Lamotte, D., Zizi, M., Missenard, Y., Hafid, M., El Azzouzi, M., Charrière, A., Maury, R.C., Taki, Z., Benammi, M., Michard, A., 2008. The Atlas system. In: Michard, A., Saddiqi, O., Chalouan, A., Frizon de Lamotte, D. (Editions), Continental Evolution: The Geology of Morocco. Springer-Verlag, Heidelberg, 133-202.

Gasquet, D., Bouloton, J., 1995. Les filons de microdiorite des Jebilet centrales (Meseta marocaine): pré-rifting permien ? Réunion extraordinaire SGF, Marrakech, Abstract volume, p.55. 
Ghorbal, B., Bertotti, G., Foeken, J., Andriessen, P., 2008. Unexpected Jurassic to Neogene vertical movements in 'stable' parts of NW Africa revealed by low temperature geochronology. Terra Nova 20, 355-363.

Guedes, A., Noronha, F., Boiron, M.C., Banks, D. A., 2002. Evolution of fluids associated with metasedimentary sequences from Chaves - North Portugal. Chemical Geology 190, 273289.

Hafid, M., 2006. Styles structuraux du Haut Atlas de Cap Tafelney et de la partie septentrionale du Haut Atlas occidental: tectonique salifère et relation entre l'Atlas et l'Atlantique. Notes Mémoires Service Géologique Maroc 465, (172 pp.).

Hart, C.J., 2007. Reduced intrusion-related gold systems. Mineral Deposits of Canada: A synthesis of major deposit types, district metallogeny, the evolution of geological provinces, and exploration methods. Geological Association of Canada, Mineral Deposits Division, Special Publication 95-112.

Heijlen, W., Banks, D.A., Muchez, P., Stensgard, B.M., Yardley, B.W.D., 2008. The Nature of Mineralising Fluids of the Kipushi Zn-Cu Deposit, Katanga, Democratic Repubic of Congo: Quantitative Fluid Inclusion Analysis using Laser Ablation ICP-MS and Bulk Crush-Leach Methods. Economic Geology 103, 1459-1482

Heijlen, W., Muchez, P., Banks, D.A., Schneider, J., Kucha, H., Keppens, E., 2003. CarbonateHosted Zn-Pb Deposits in Upper Silesia, Poland: Origin and Evolution of Mineralizing Fluids and Constraints on Genetic Models. Economic Geology 98, 911-932.

Huff, T.A., Nabelek, P.I., 2007. Production of carbonic fluids during metamorphism of graphitic pelites in a collisional orogeny. An assessment from fluid inclusions. Geochimica. Cosmochimica. Acta 71, 4997-5015.

Huizenga, J.M., 2001. Thermodynamic modeling of C-O-H fluids. Lithos 55, 101-114

Huon, S., Cornée, J.J., Piqué, A., Raïs, N., Clauer, N., Liewig, N., Zayane, R., 1993. Mise en évidence au Maroc d'événements thermiques d'âge triasico-liasique liés à l'ouverture de l'Atlantique. Bulletin Société Géologique de France 164, 165-176.

Huvelin, P., 1961. Sur l'âge viséen supérieur des schistes de Kettara et du Jbel Sarhlef (Jebilet centrales, Maroc). Comptes Rendus Sommaires Société Géologique de France, 290-291.

Huvelin, P., 1972. Carte géologique des minéralisations des Jebilet centrales au 1/100.000. Notes Mémoires Service Géologique Maroc 232a.

Huvelin, P., 1977. Etude géologique et gîtologique du massif hercynien des Jebilet (Maroc occidental). Notes Mémoires Service Géologique Maroc 232bis, (308 pp.). 
Jalil, N., 1999. Continental Permian and Triassic vertebrate localities from Algeria and Morocco and their stratigraphical correlations. Journal of African Earth Sciences 29, 219226.

Krutilin, V.N., Titov, V.,I. , Maacha, L., Zouhair, M., 2013. The gold mineralisation in Central Jebilet, Morocco: FOREIGN EXPERIENCE: UDC 553.04 (64). Education and science in Russia and abroad; N5/2013. ISSN 2221-4607; in Russian.

Lagarde, J.L., Choukroune, P., 1982. Cisaillement ductile et granitö̈des syntectoniques: l'exemple du massif hercynien des Jebilet (Maroc). Bulletin Société Géologique de France 24, 299-307.

Lang, J.R., Baker, T., 2001. Intrusion-related gold systems: the present level of understanding. Mineralium Deposita 36, 477-489.

Laville, E., Piqué A., 1991. La distension crustale atlantique et atlasique au Maroc au début du Mésozoïque: le rejeu des structures hercyniennes. Bulletin Société Géologique de France $162,1161-1171$.

Le Corre, C., Bouloton, J., 1987. Un modèle de 'structure en fleur'” associant décrochement et convergence: les Jebilet centro-occidentales (Maroc hercynien). Comptes Rendus Académie Sciences Paris, (Série II), 13, 751-755.

Leisen, M., Dubessy, J., Boiron, M.C., Lach P., 2012a, Improvement of the determination of element concentrations in quartz-hosted fluid inclusions by LA-ICP-MS and Pitzer thermodynamic modeling of ice melting temperature. Geochimica et Cosmochimica Acta 90, 110-125.

Leisen, M., Boiron, M.C., Richard, A., Dubessy, J., 2012b. Determination of $\mathrm{Cl}$ and $\mathrm{Br}$ concentrations in individual fluid inclusions by combining microthermometry and LAICPMS analysis: Implications for the origin of salinity in crustal fluids. Chemical Geology 330-331, 197-206.

Longerich, H.P., Jackson, S.E., Gunther, D., 1996. Laser ablation inductively coupled plasma mass spectrometric transient signal data acquisition and analyte concentration calculation. Journal of Analytical Atomic Spectrometry 11, 899-904.

Margoum, D., Bouabdellah, M., Klügel, A., Banks, D.A., Castorina, F., Cuney, M., Jébrak, M., Bozkaya, G., 2015. Pangean rifting and onward pre-Central Atlantic opening as the main ore-forming processes for the genesis of the Aouli REE-rich fluorite-barite vein system, Upper Moulouya District, Morocco. Journal of African Earth Sciences 108, 22-39. 
Medina, F., 1991. Superimposed extensional tectonics in the Argana Triassic formations (Morocco), related to the early rifting of the Central Atlantic. Geological Magazine 128, $525-536$.

Medina, F., Vachard, D., Colin, J.P., Ouarhache, D., Ahmamou, M., 2001. Charophytes et ostracodes du niveau carbonate de Taourirt Imzilen (Membre d'Aglegal, Trias d'Argana); implications stratigraphiques. Bulletin Institut Scientifique Rabat 23, 21-26.

Mrini, Z., Rafi, A., Duthou, J.L., Vidal, P., 1992. Chronologie Rb-Sr des granitoïdes hercyniens du Maroc: conséquences. Bulletin Société Géologique de France 163, 281-291.

Nadoll, P., Sośnicka, M., Kraemer, D., Duschl, F., 2019. Post-Variscan structurally-controlled hydrothermal $\mathrm{Zn}-\mathrm{Fe}-\mathrm{Pb}$ sulfide and F-Ba mineralisation in deep-seated Paleozoic units of the North German Basin: A review. Ore Geology Reviews 106, 273-299.

N'Diaye, I., Essaifi, A., Dubois, M., Lacroix, B., Goodenough, K.M., Maacha, L., 2016. Fluid flow and polymetallic sulfide mineralisation in the Kettara shear zone (Jebilet Massif, Variscan Belt, Morocco). Journal of African Earth Sciences 119, 17-37

Neiva, A.M.R., Moura, A., Carvalho, P.C.S., 2015. Metallogenesis at the Terramonte Pb-ZnAg quartz vein, Portugal: geological, mineralogical and geochemical evidences. Ore Geology Reviews 71, 14-28.

Nshimiyimana, F., Essarraj, S., Hibti, M., Boulvais, Ph., Boyce, A.J., Marignac, Ch., Maacha, L., 2018. The Koudia El Hamra Ag-Pb-Zn deposit, Jebilet, Morocco: Mineralogy and ore fluid characterisation. Journal of African Earth Sciences 145, 1-17.

Outigua, A., Essaifi, A., Corsini, M., Outhounjite M., Zouhair, M., 2020. Sidi M'Barek: a representative example of the Moroccan massive sulphide deposits. Geological Society, London, Special Publications, 502, xx.

Piqué, A., Canals, A., Grandia, F., and Banks, D.A., 2008. Mesozoic fluorite veins in NE Spain record regional base metal-rich brine circulation through basin and basement during extensional events. Chemical Geology 257, 139-152.

Piqué, A., Jeannette, D., Michard, A., 1980. The Western Meseta Shear Zone, a major and permanent feature of the Variscan belt in Morocco. Journal of structural Geology 2, 55-61.

Piqué, A., Laville, E., 1993. L'ouverture de l'Atlantique central: un rejeu en extension des structures paléozoïques. Comptes Rendus de l'Académie des Sciences Paris 317, II, 13251328.

Piqué, A., Laville, E., 1996. The central Atlantic rifting: reactivation of Palaeozoic structures. Journal of Geodynamics 21, 235-255. 
Richard, A., Cathelineau, M., Boiron, M.C., Mercadier, J., Banks, D.A., Cuney, M., 2016. Metal-rich fluid inclusions provide new insights into unconformity-related $\mathrm{U}$ deposits (Athabasca Basin and Basement, Canada). Mineralium Deposita 51, 249-270.

Roedder, E., 1984. Fluid Inclusions. Reviews in Mineralogy 12, Mineralogical Society of America (644 pp.).

Rossi, M., Gasquet, D., Cheilletz, A., Tarrieu, L., Bounajma, H., Mantoy, T., Reisberg, L., Deloule, E., Boulvais, P., Burnard, P., 2016. Isotopic and geochemical constraints on lead and fluid sources of the $\mathrm{Pb}-\mathrm{Zn}-\mathrm{Ag}$ mineralisation in the polymetallic Tighza-Jbel Aouam district (central Morocco), and relationships with the geodynamic context. Journal of African Earth Sciences 127, 194-210.

Saddiqi, O., El Haïmer, F., Michard, A., Barbarand, J., Ruiz, G.M.H., Mansour E.M., Leturmy, P., Frizon de Lamotte, D., 2009. Apatite fission-track analyses on basement granites from south-western Meseta, Morocco: Paleogeographic implications and interpretation of AFT age discrepancies. Tectonophysics 475, 29-37.

Shepherd, T.J., 1981. Temperature- programmable heating-freezing stage for microthermometric analysis of fluid inclusion. Economic Geology 76, 1244-1247

Sheppard, M.F., 1986. Characterisation and isotopic variations in natural waters, in Valley et al. eds., stable isotopes in high temperature geological processes. Reviews in mineralogy, Mineralogical Society of America 16, 165-183.

Sial, A.N., Bettencourt, J.S., De Campos, C. P., Ferreira, V.P., 2011. Granite-related ore deposits: an introduction. Geological Society of London, Special Publications 350, 1-5.

Steele-MacInnis, M., Bodnar, R.J., Naden, J., 2011. Numerical model to determine the composition of $\mathrm{H} 2 \mathrm{O}-\mathrm{NaCl}-\mathrm{CaCl} 2$ fluid inclusions based on microthermometric and microanalytical data. Geochimica et Cosmochimica Acta 75, 21-40.

Studer, M.A., 1987. Tectonique et pétrographie des roches sédimentaires, éruptives et métamorphiques de la région de Tounfite-Tirrhist (Haut Atlas central mésozoïque, Maroc). Notes et Mémoires Service Géologique Maroc 43, 321, 65-197.

Thiéry, R., van den Kerkhof, A.M., Dubessy, J., 1994. vX properties of $\mathrm{CH}_{4}-\mathrm{CO}_{2}$ and $\mathrm{CO}_{2}-\mathrm{N}_{2}$ fluid inclusions: Modelling for T, $31^{\circ} \mathrm{C}$ and P, 400 bar. European Journal of Mineralogy 6 , 753-771.

Thompson, J.F.H., Sillitoe, R.H., Baker, T., Lang, J.R., Mortensen, J.K., 1999. Intrusionrelated gold deposits associated with tungsten-tin provinces. Mineralium Deposita 34, 323334. 
Thompson, J.F.H., Newberry, R.J., 2000. Gold deposits related to reduced granitic intrusions, in: Hagemann, S.G., Brown, P.E. (Eds.), Review in Economic Geology: Gold in 2000. Society of Economic Geology, Inc, Boulder, 377-400.Tisserant, D., 1977. Les isotopes du strontium et l'histoire hercynienne du Maroc. Etude de quelques massifs atlasiques et mésétiens. Unpublished PhD thesis, University of Strasbourg, France (103 pp.).

Tourani, A., Lund, J.J., Banaouiss, N., Gaupp, R., 2000. Stratigraphy of Triassic syn-rift deposits in western Morocco, in Bacman G.H., Larche I. (Editions), Epicontinental Triassic, Zentralblatt Mineralogie, Geologie und Paläontologie, 1193-1215.

Valenza, K., Moritz, R., Mouttaqi, A., Fontignie, D., Sharp, Z., 2000. Vein and karst barite deposits in the western Jebilet of Morocco: fluid inclusion and isotope ( $\mathrm{S}, \mathrm{O}, \mathrm{Sr}$ ) evidence for regional fluid mixing related to Central Atlantic rifting. Economic Geology 95, 587-606.

Walter, B.F., Burisch, M., Mark1, G., 2016. Long-term chemical evolution and modification of continental basement brines - a field study from the Schwarzwald, SW Germany. Geofluids $16,604-623$.

Walter, B.F., Kortenbruck, P., Scharrer, M., Zeitvogel, C., Wälle, M., Mertz-Kraus, R., Markl, G., 2019. Chemical evolution of ore-forming brines - Basement leaching, metal provenance, and the redox link between barren and ore-bearing hydrothermal veins. A case study from the Schwarzwald mining district in SW-Germany. Chemical Geology 506, 126-148.

Wang, Y., Wang K., Konare, Y., 2018. $\mathrm{N}_{2}$-rich fluid in the vein-type Yangjingou scheelite deposit, Yanbian, NE China. Scientific Reports 8, 5662.

Warme, J.E., 1988. Jurassic carbonate facies of the central and eastern High Atlas rift, Morocco. In: Jacobshagen, V. (Edition), The Atlas System of Morocco. Lecture Notes Earth Sciences $15,169-199$.

Weisbrod, A., 1984. Utilisation des inclusions fluides en géothermobarométrie. In : Lagache, M. (Edition), Thermométrie et Barométrie Géologiques. Société Française de Minéralogie et de Cristallographie, 415-459.

Wilkinson, J.J., 2001. Fluid inclusions in hydrothermal ore deposits. Lithos 55, 229-272.

Wilkinson, J.J., Stoffell, B., Wilkinson, C.C., Jeffries, T.E., Appold, M.S., 2009. Anomalously metal-rich fluids form hydrothermal ore deposits. Science 323, 5915, 764-767.

Wright, A.J., Blamey, N.J.F., Conliffe, J., Costanzo, A., Parnell, J., 2012. Origin of veingraphite derived from metamorphic fluids in Moine (Glenfinnan Group) rocks, NW Scotland. Scottish Journal of Geology 48, 1, 47-59.

Yardley, B.W.D., 2005. 100th Anniversary Special Paper: metal concentrations in crustal fluids and their relationship to ore formation. Economic Geology 100, 4, 613-632. 
927 Youbi, N., Bellon, H., Marzin, A., Piqué, A., Cotten, J., Cabanis, B., 2001. Du cycle orogénique 928 hercynien au pré-rifting de l'Atlantique central au Maroc occidental: les microdiorites des 929 Jbilet sont-elles des marqueurs magmatiques de ce passage? Comptes Rendus Académie $930 \quad$ Sciences Paris 333, 295-302.

931 Zhong, R., Brugger, J., Chen, Y., Li, W., 2015. Contrasting regimes of $\mathrm{Cu}, \mathrm{Zn}$ and $\mathrm{Pb}$ transport 932 in ore-forming hydrothermal fluids. Chemical Geology 395, 24, 154--164. 


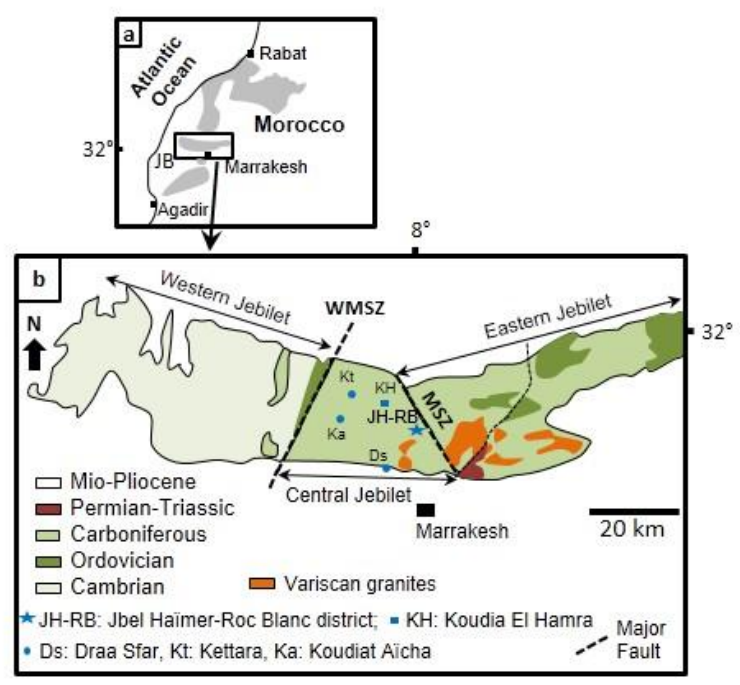

934

935

936

937
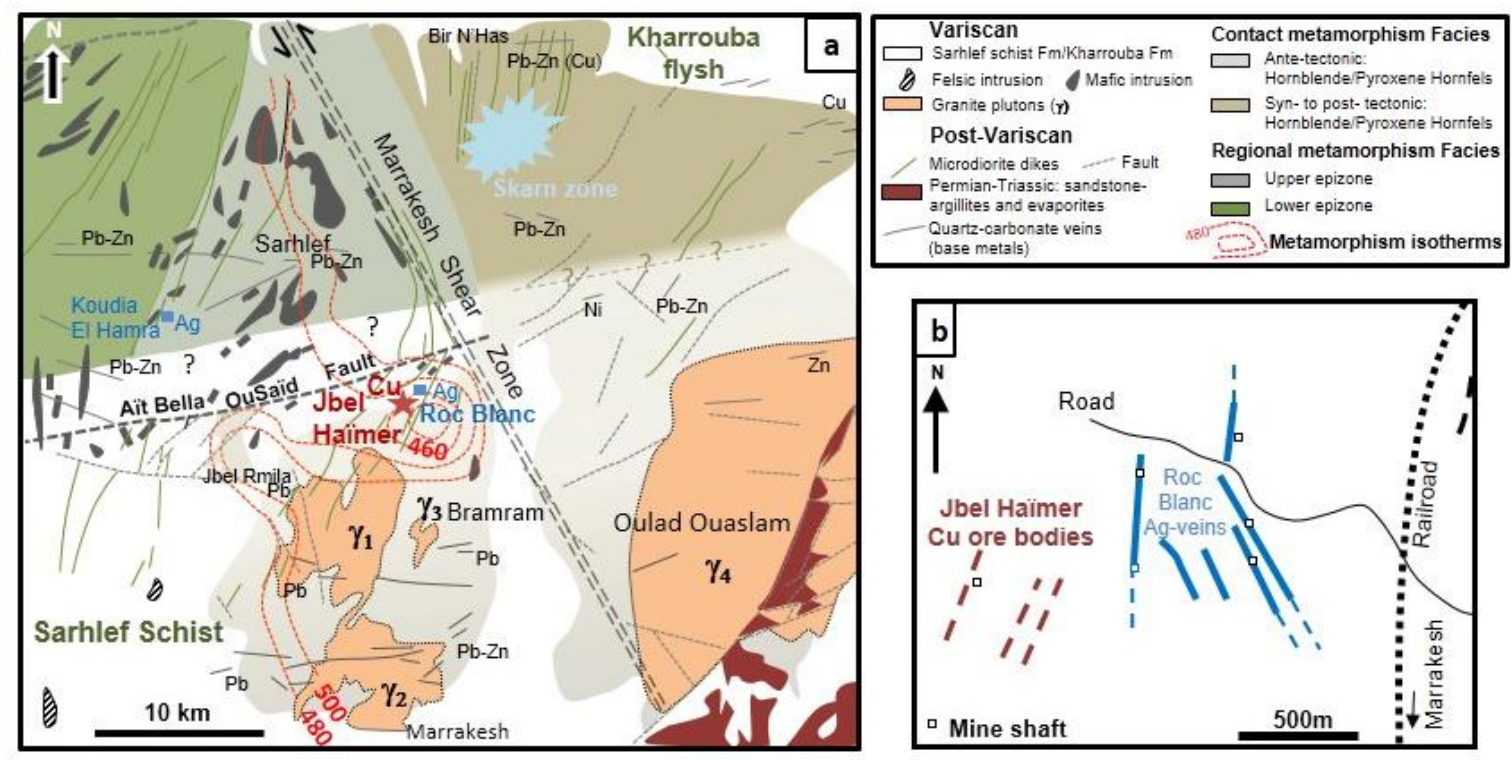

Fig. 1. a Location of the Variscan massifs in Morocco (in grey: central-meridional domain), JB: Jebilet. b Geology of the Jebilet massif (Huvelin, 1977; in Bernard et al., 1988), and location of the main deposits: the Jbel Haïmer and Roc Blanc (Ag) district, the Koudia El Hamra Ag deposit, and the main volcanogenic massive sulphide deposits (VMS pyrrhotite-polymetallic lenses): Draa Sfar, Koudiat Aicha and Kettara, from Huvelin (1977). (MSZ: Marrakesh Shear Zone; WMSZ: West Moroccan Shear Zone, see text for references).

Fig. 2. a Location of base metal and silver ore veins (deposits and occurrences) with the indication of major faults in the Central Jebilet around Jbel Haïmer and Western part of the 
947 Eastern Jebilet (from Huvelin, 1972); only kilometre size faults are represented. $\gamma$ : granites 1, 948 2, 3 and 4: Tabouchennt, Bamega, Bramram and Oulad Ouaslam respectively. The Jbel Haïmer949 Roc Blanc district is detailed in b. Metamorphism facies and isotherms of thermal 950 metamorphism M2 are reported from Delchini et al. (2018) and Delchini (2018); skarn zone: 951 from Huvelin (1977), studied by Bastoul, (1992). b Schematic map of the mining works of the 952 Jbel Haïmer (main ore bodies) and Roc Blanc Ag- ore bodies (From Huvelin 1977). 

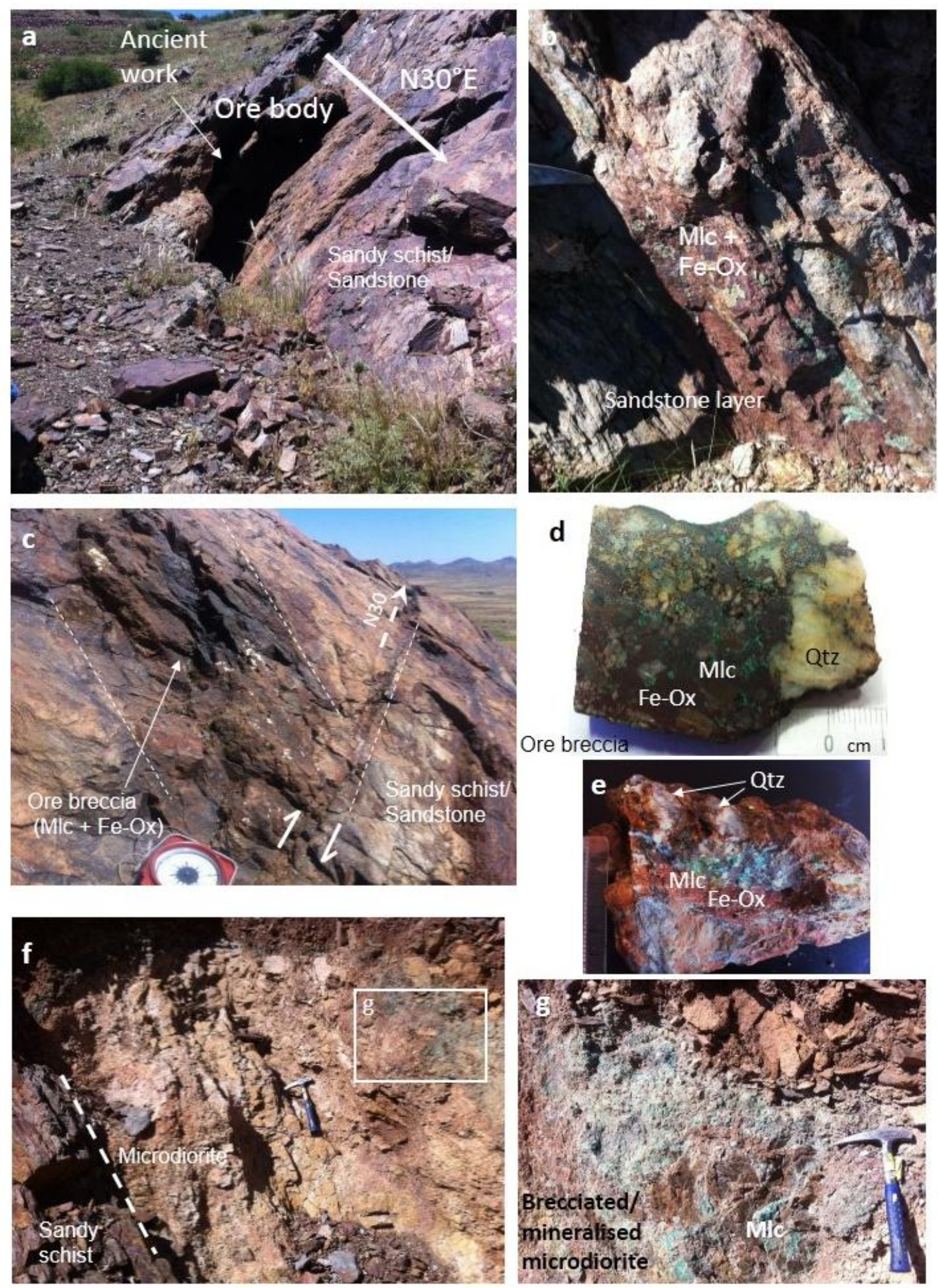

954 Fig. 3. a, b, c, f, g Field exposures of the Jbel Haïmer area showing gossan: oxidised ores 955 (malachite (Mlc) and Fe-oxides (Fe-Ox) sandy schist/sandstone and brecciated/altered 956 microdiorite dike. $\mathbf{d}$ and $\mathbf{e}$ : hand specimens showing ore breccia with quartz (Qtz) fragments impregnated with malachite and Fe-oxides 


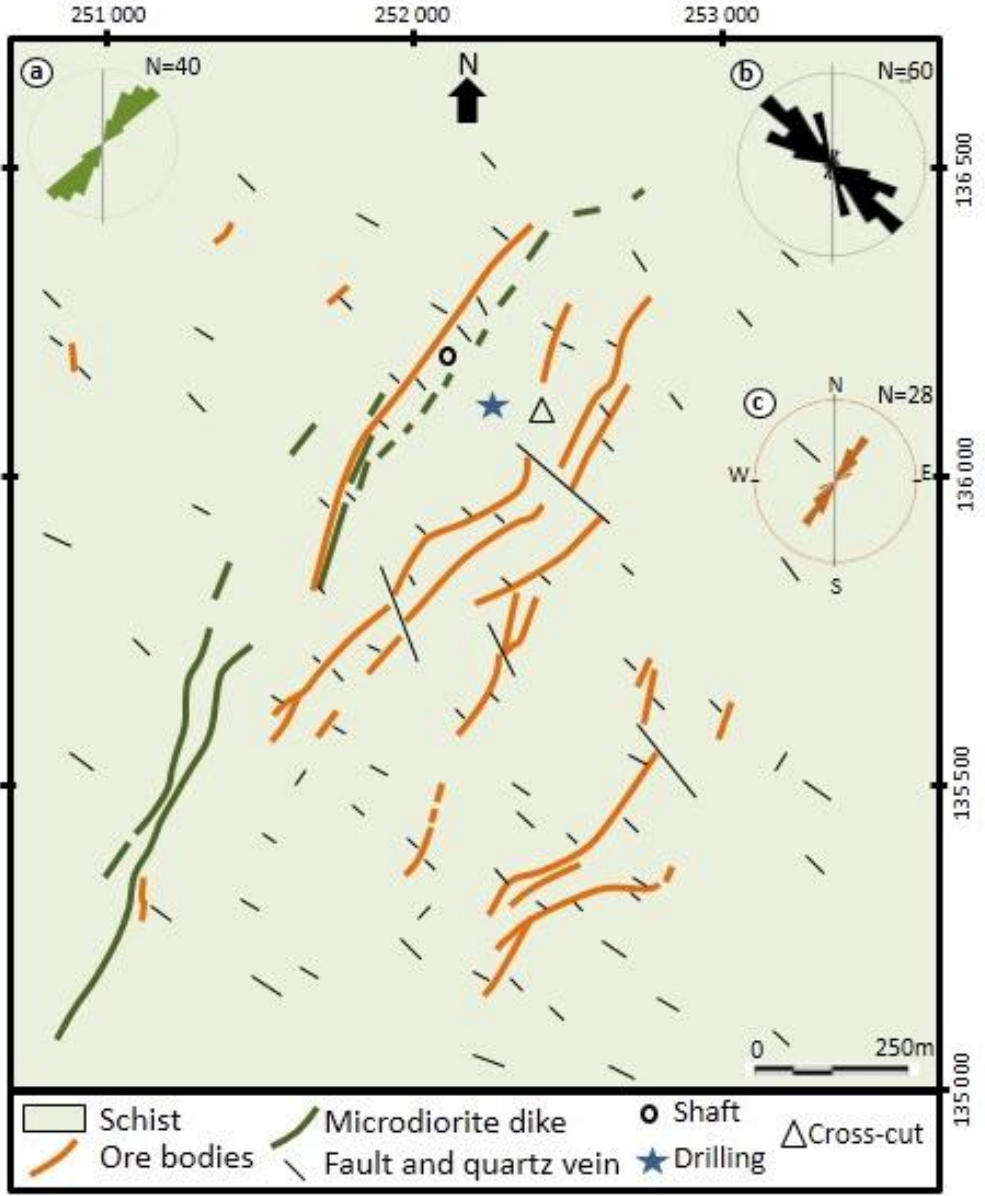

959 Fig. 4. Representation of fractures, main ore bodies, and microdiorite dikes subparallel to local 960 schistosity (S1) in the Jbel Haïmer area. a, b, c rose-diagrams corresponding respectively to 961 schistosity, fractures, and veins, and ore bodies (Boutira and Hakkou, 2012; in Essarraj et al., 962 2013), N: number of measurements. 

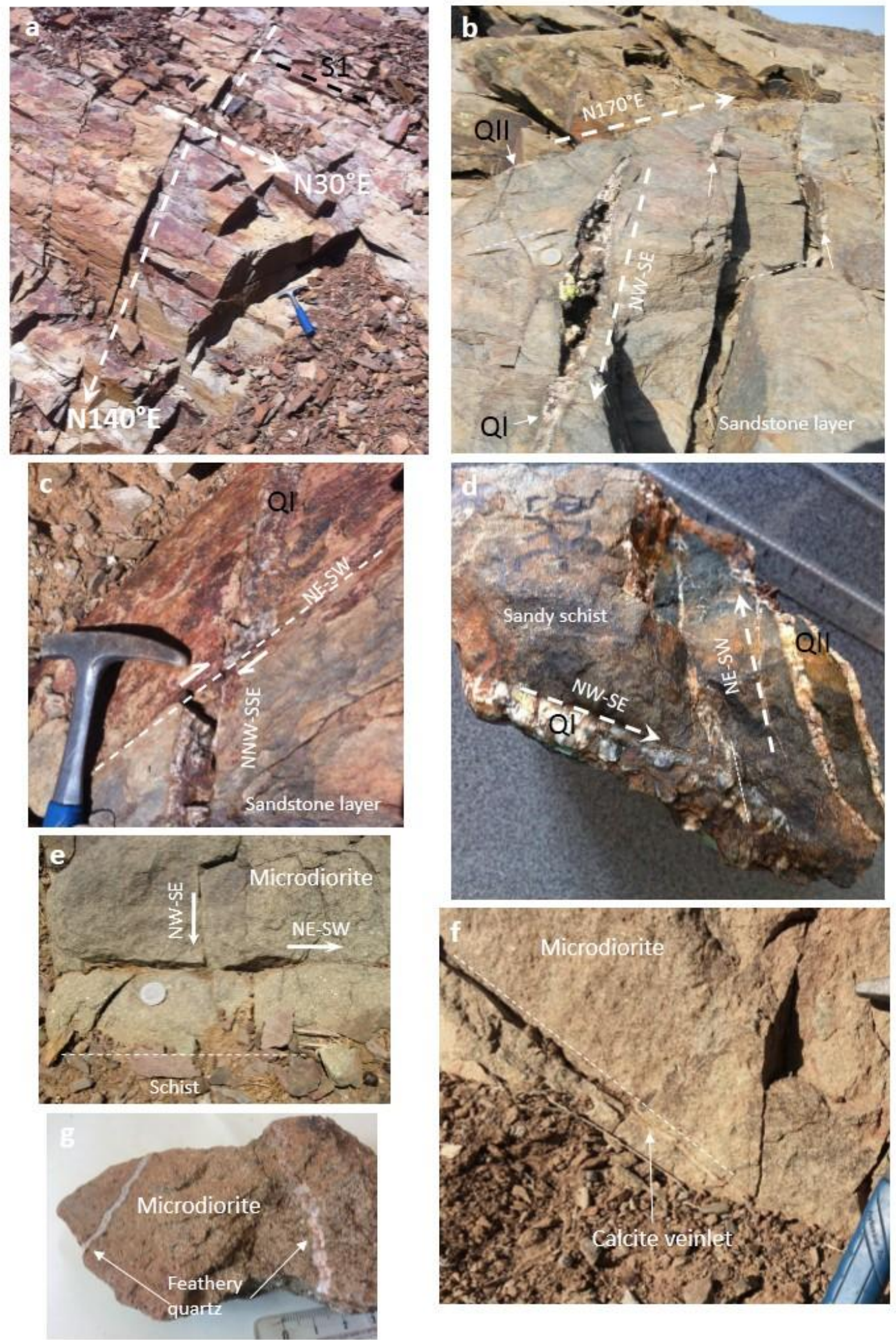

964 Fig. 5. a, b, c, d Relationships between schistosity, fractures and veins crosscutting sandy schist 965 and sandstone layers; QI and QII: early quartz (see text for description). e fractures in 966 microdiorite, f Calcite veinlet crosscutting microdiorite, $\mathbf{g}$ Feathery quartz veinlets crosscutting microdiorite. 

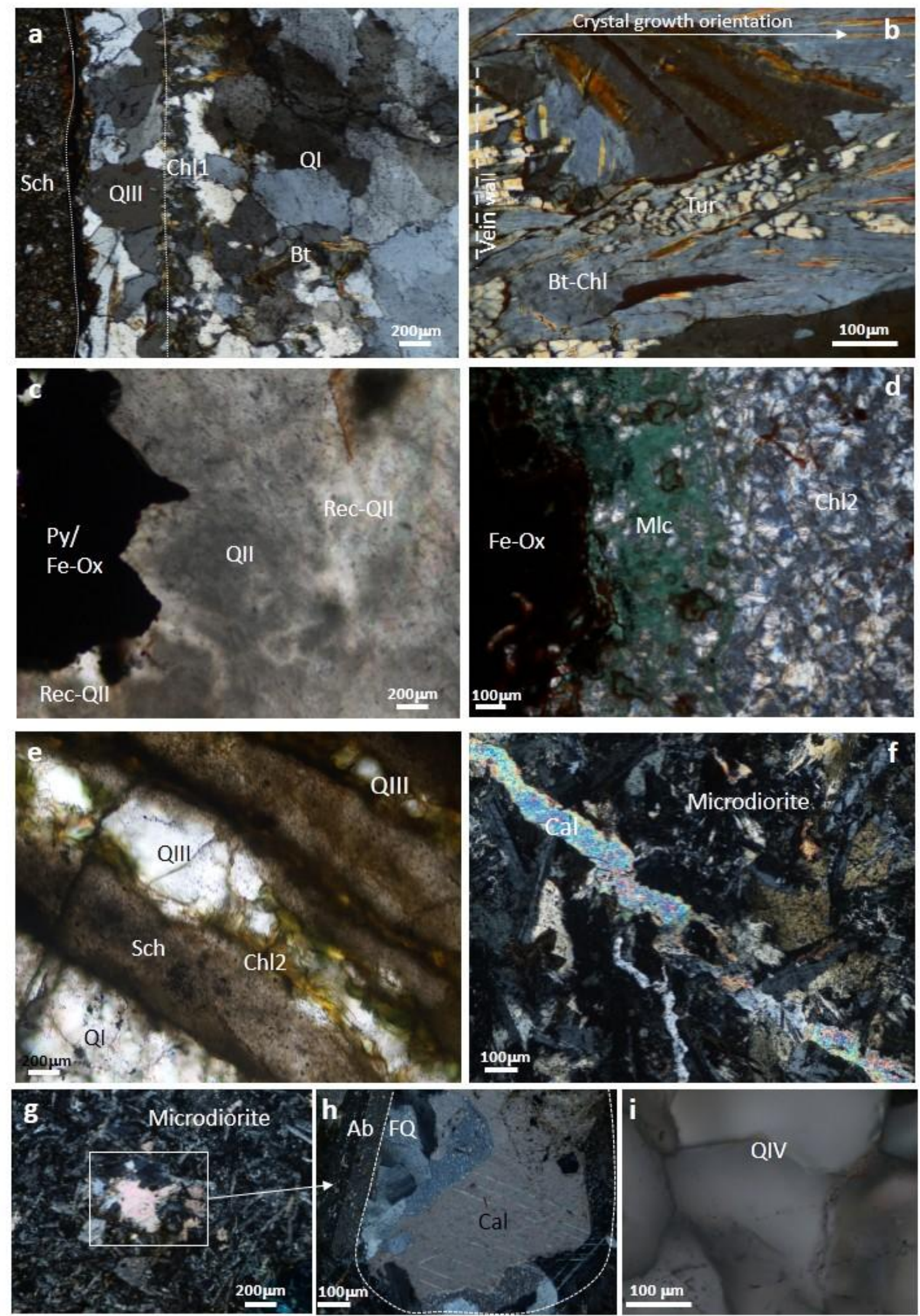

969 Fig. 6. Mineralogy of Jbel Haïmer. a NW-SE vein with deformed and cloudy quartz (QI) and chloritised biotite (Chl1)-(Bt), crosscutting schist (Sch), and newly formed quartz veinlet with 
971 undeformed quartz (QIII). b chloritised biotite (Bt-Chl) and brecciated tourmaline crystals (Tur)

972 perpendicular to the QI vein wall. c Cloudy QII quartz with strongly oxidised pyrite (Py/Fe-

973 Ox) in the core of QII vein, Rec-QII: recrystallisation microdomains in QII around pyrite. d 974 Malachite (Mlc), Fe-oxides (Fe-Ox), and chlorite 2 (Chl2) invading the QI vein core. e 975 Undeformed QIII-chlorite 2 (Chl2) veinlet parallel to QI (deformed) vein, both crosscutting 976 schist (Sch). f calcite veinlet crosscutting microdiorite. $\mathbf{g}$ Micro-vacuole in microdiorite filled 977 with late minerals (detail in H). h Undeformed feathery quartz (FQ), then calcite (Cal) filling a 978 vacuole in microdiorite, Ab: albite from microdiorite. i Late geodic quartz QIV poor in fluid 979 inclusions and FIP. 

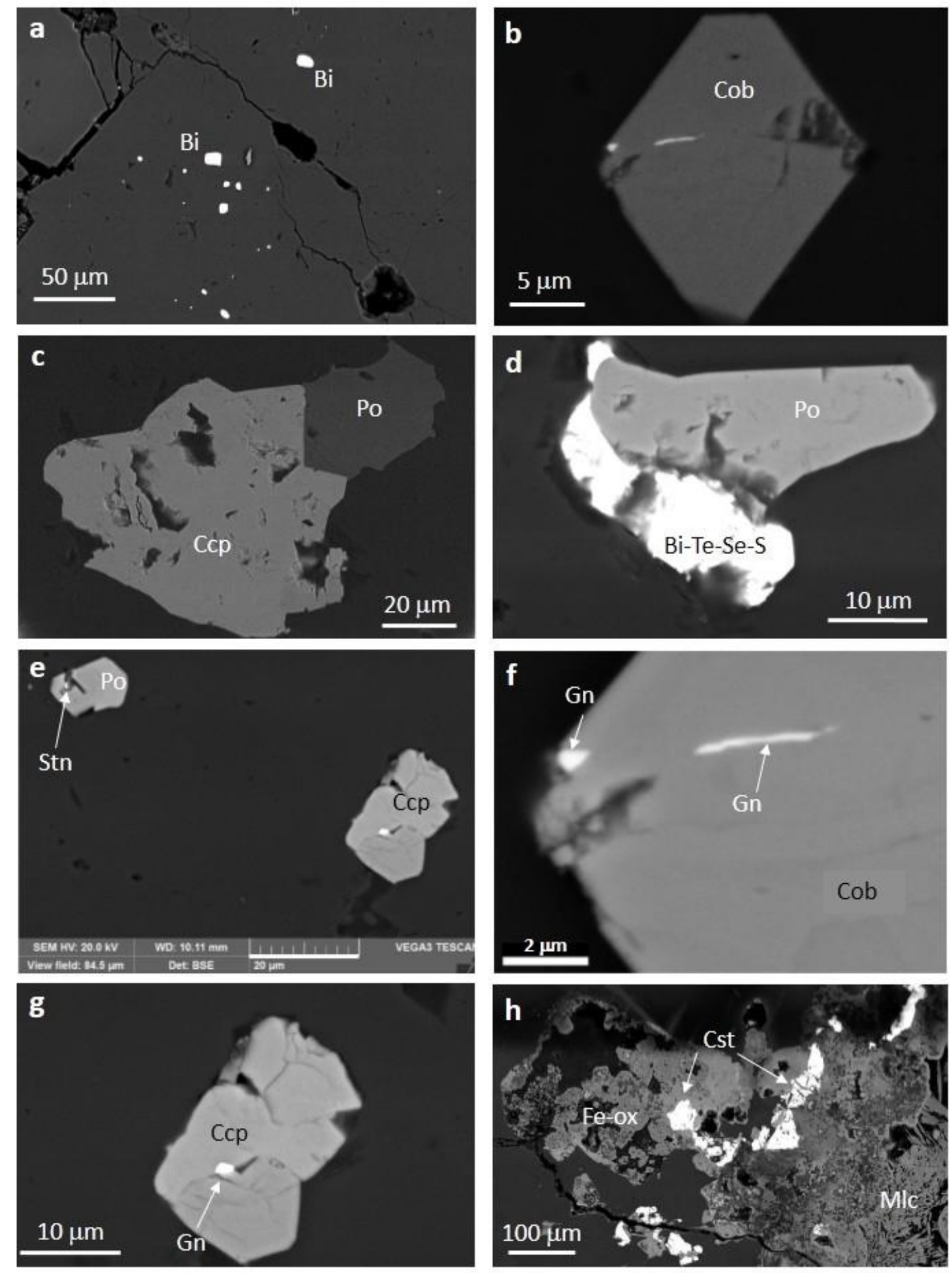

981 Fig. 7. Ore minerals from Jbel Haïmer observed by scanning electron microscope. a Bismuth 982 and bismuthinite blebs (Bi). b cobaltite euhedral crystal (Cob). c Chalcopyrite (Ccp) 983 crystallising over pyrrhotite (Po). d Bi-Te-Se-S mineral growing over pyrrhotite (Po). e Stannite 984 (Stn) in fracture of pyrrhotite (Po). f galena (Gn) in microfracture crosscutting cobaltite (Cob). 985 g Galena ( $\mathrm{Gn}$ ) in microfracture crosscutting chalcopyrite (Ccp). h Malachite (Mlc), Cassiterite 986 (Cst), and Fe-oxides in oxidised ore. 

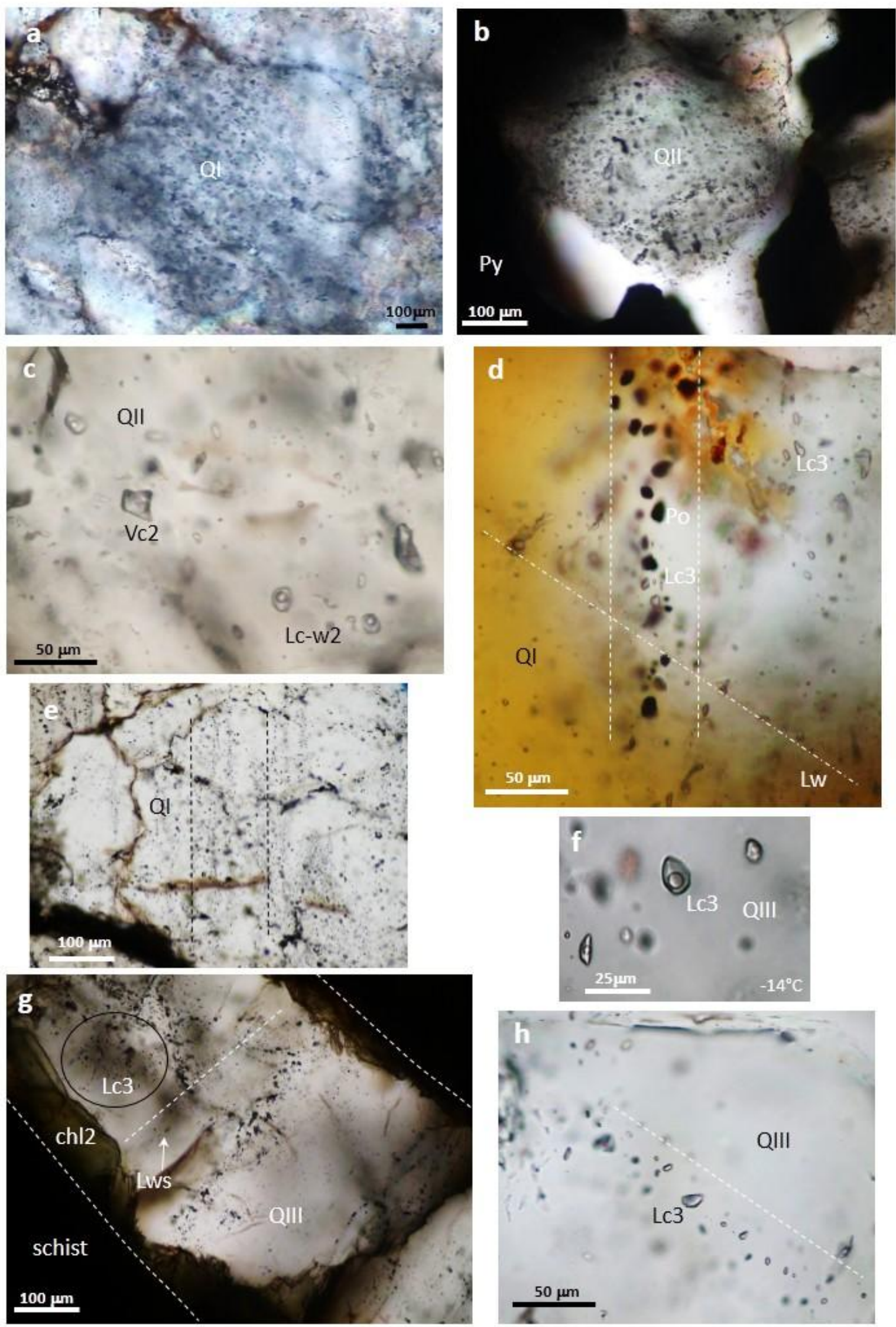
989

990

991

992

993

994

995

996

997

Fig. 8. Fluid inclusions (FIs) from Jbel Haïmer: early stages. a QI darkened by FIs clouds from different generations. b QII quartz recrystallised around pyrite crystals (Py) and late sulphides assemblages. c FIs in QII. d Lc3 FIs synchronous with small pyrrhotite crystals: Lc3 FIs and pyrrhotite microcrystals are trapped in the same microfracture crosscut by an aqueous fluid inclusion (Lw) plane. e Lc3 FIP network parallel to NW-SE QI veins. f Lc3 FIs (two-phase at $14^{\circ} \mathrm{C}$ ). g Lc3 FIs cloud (circle) in NW-SE QIII - chlorite 2 (Chl2) vein, and Lws aqueous FIP perpendicular to QIII vein. h Lc3 FIs pseudo-secondary in QIII vein. See text for description of fluid inclusion types.

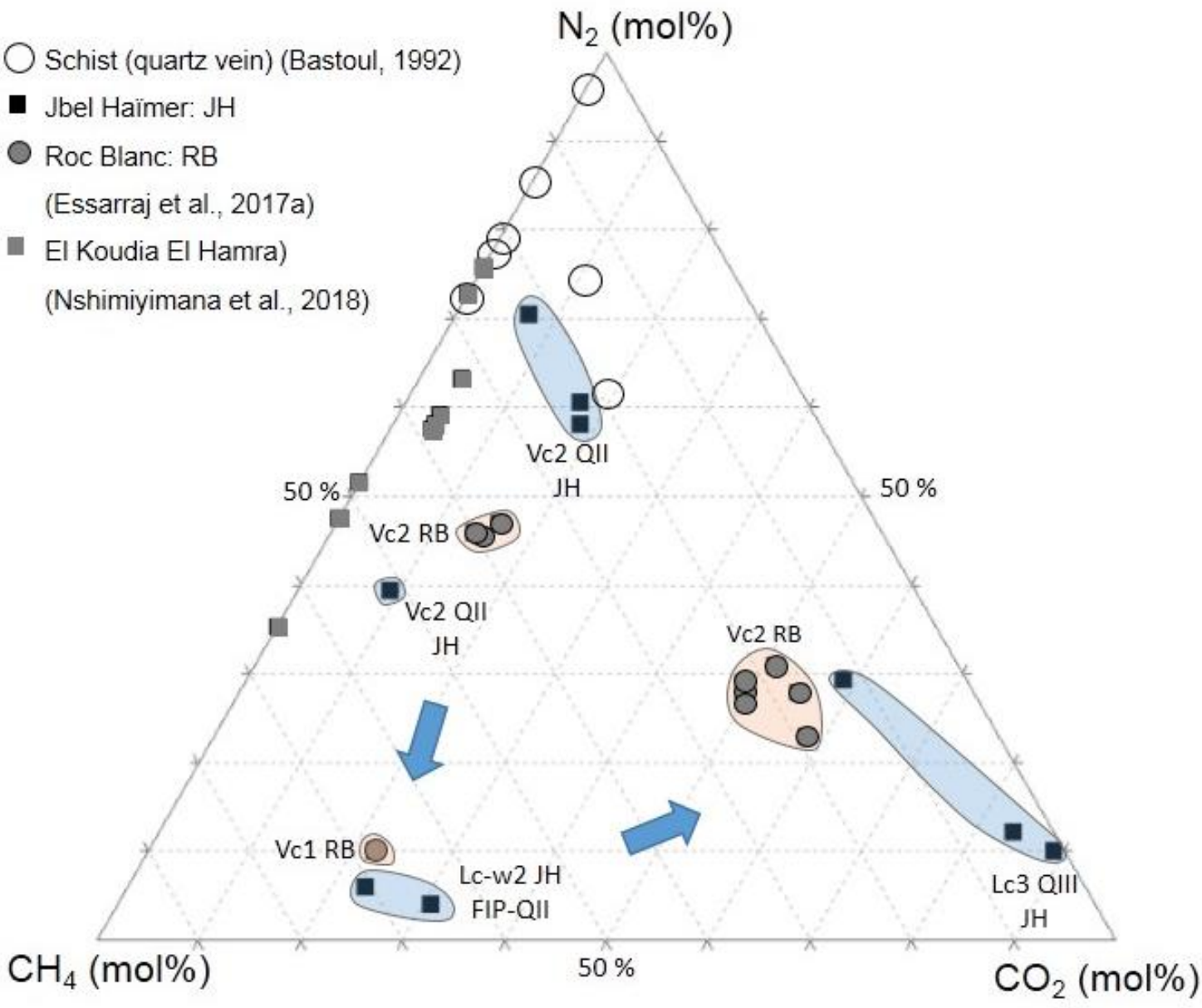

998

999

1000

1001

1002

Fig. 9. $\mathrm{CO}_{2}-\mathrm{CH}_{4}-\mathrm{N}_{2}$ ternary diagram presenting Raman data for FIs from Jbel Haïmer compared with data from vapour fluid inclusions from the Roc Blanc and the Koudia El Hamra silver deposits and a quartz vein (Bastoul, 1992) crosscutting the Sarhlef schist in central Jebilet. Arrows indicate the evolution of fluid inclusion composition over time. 

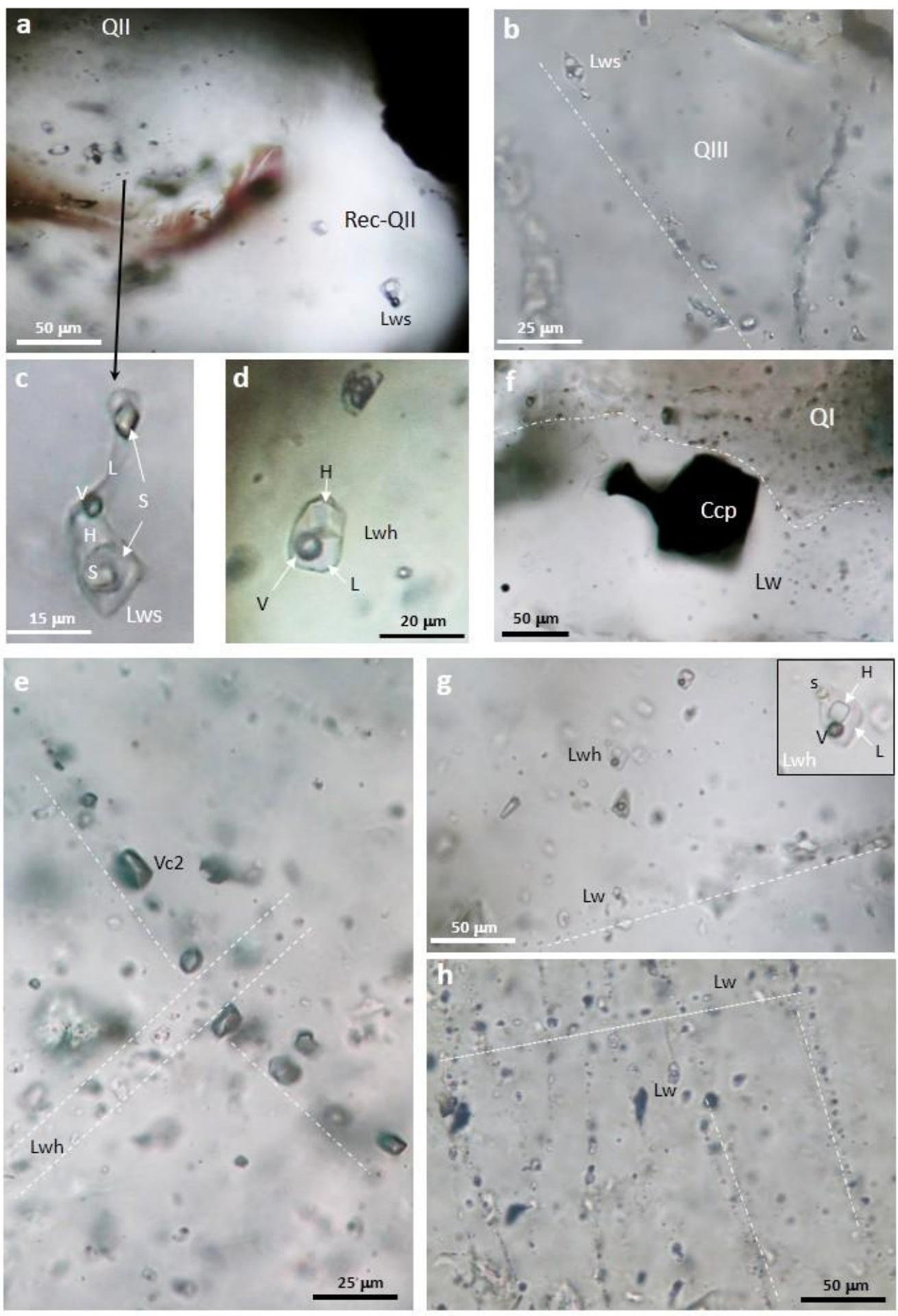

1004 Fig. 10. Fluid inclusions from the late stages at Jbel Haïmer. a Lws FIs in recrystallised QII 1005 quartz (Rec-QII). b Lws FIPs in QIII. c Lws FI showing halite cube and 3 solids. d Lwh FI. e 1006 Lwh FIs crosscutting one phase carbonic FIP in QIII. f recrystallised cloudy quartz QI around 1007 chalcopyrite crystal (fluid inclusion poor), scarce Lw FIs. g Aqueous FIP (Lw) crosscutting 1008 Lwh FI assemblage in QIV. h Perpendicular FIP sets crosscutting QI quartz vein. 


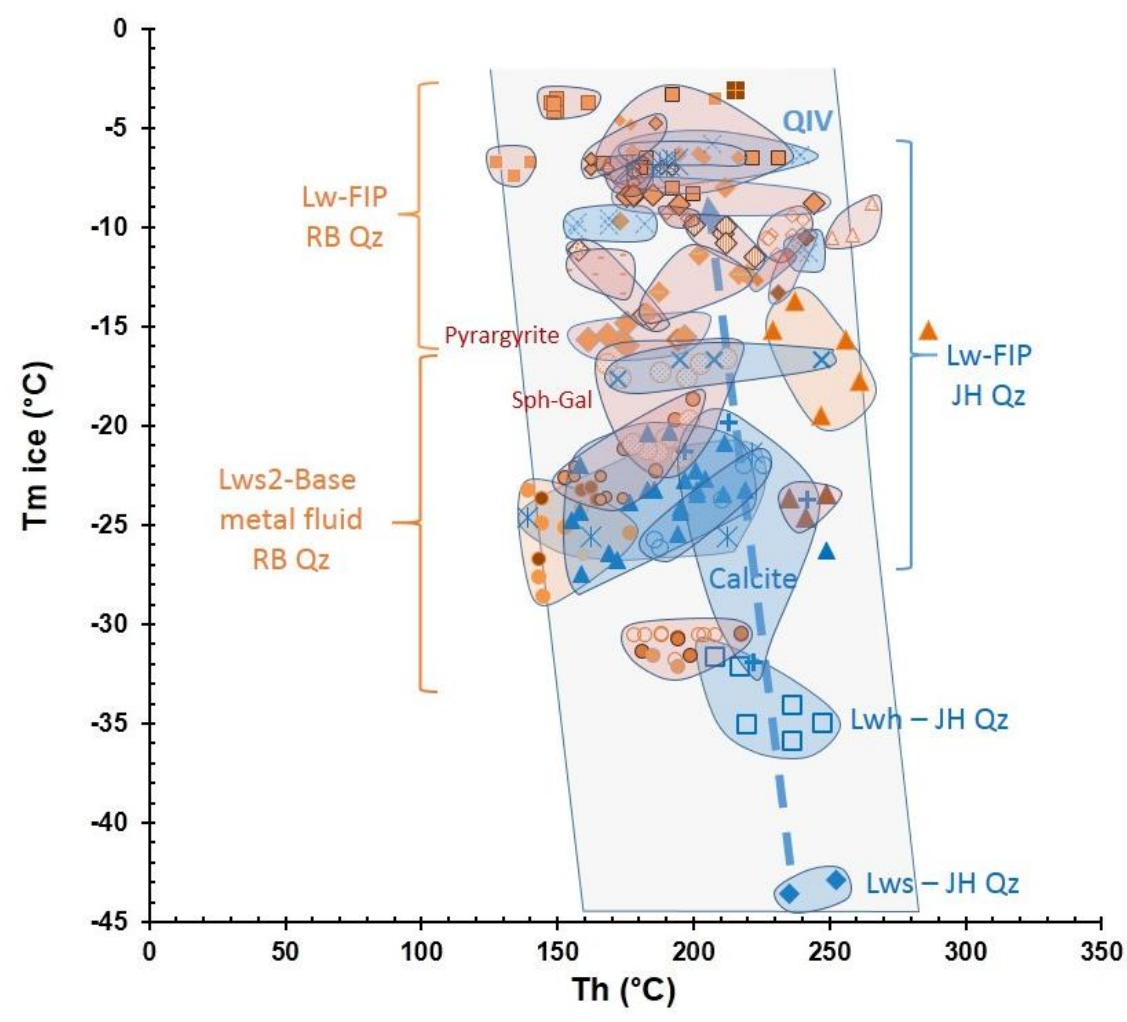

1009

1010 Fig. 11. Tm ice vs Th for aqueous fluid inclusions from Jbel Haïmer (in blue). For comparison, 1011 data for aqueous fluid inclusions from the Roc Blanc deposit are presented (in orange) (from 1012 Essarraj et al., 2017a). Different symbols correspond to different FIPs. Arrow represents the 1013 mixing trend described in the text. JH Qz: FIs in quartz from Jbel Haïmer, RB Qz: FIs in quartz 1014 from Roc Blanc, calcite domain: FIs in calcite from Jbel Haïmer. Sph-Gal and pyrargyrite: FIs 1015 associated respectively to sphalerite - galena and pyrargyrite from Roc Blanc (Essarraj et al., 1016 2017a). See text for fluid inclusions types and comments. 


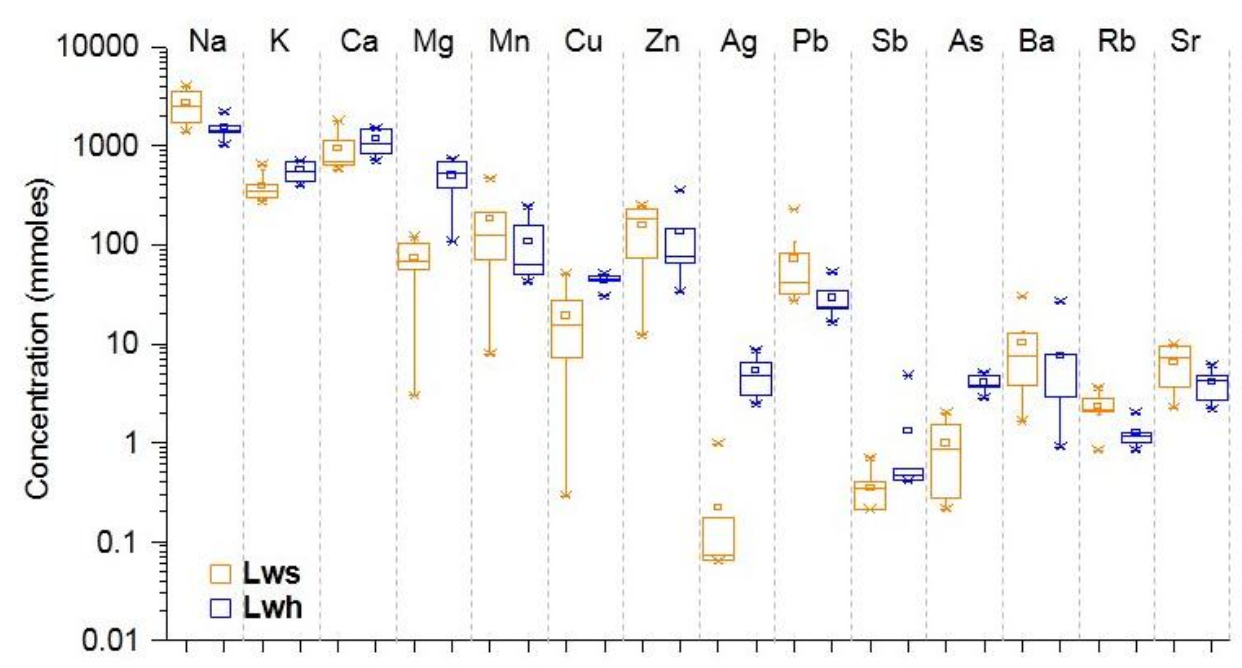

1018

1019 Fig. 12. Range of the major, minor, and trace element compositions (in $\mathrm{mmol} / \mathrm{kg}$ of solution) of the Lws and Lwh brines from Jbel Haïmer, analysed by LA-ICP-MS.

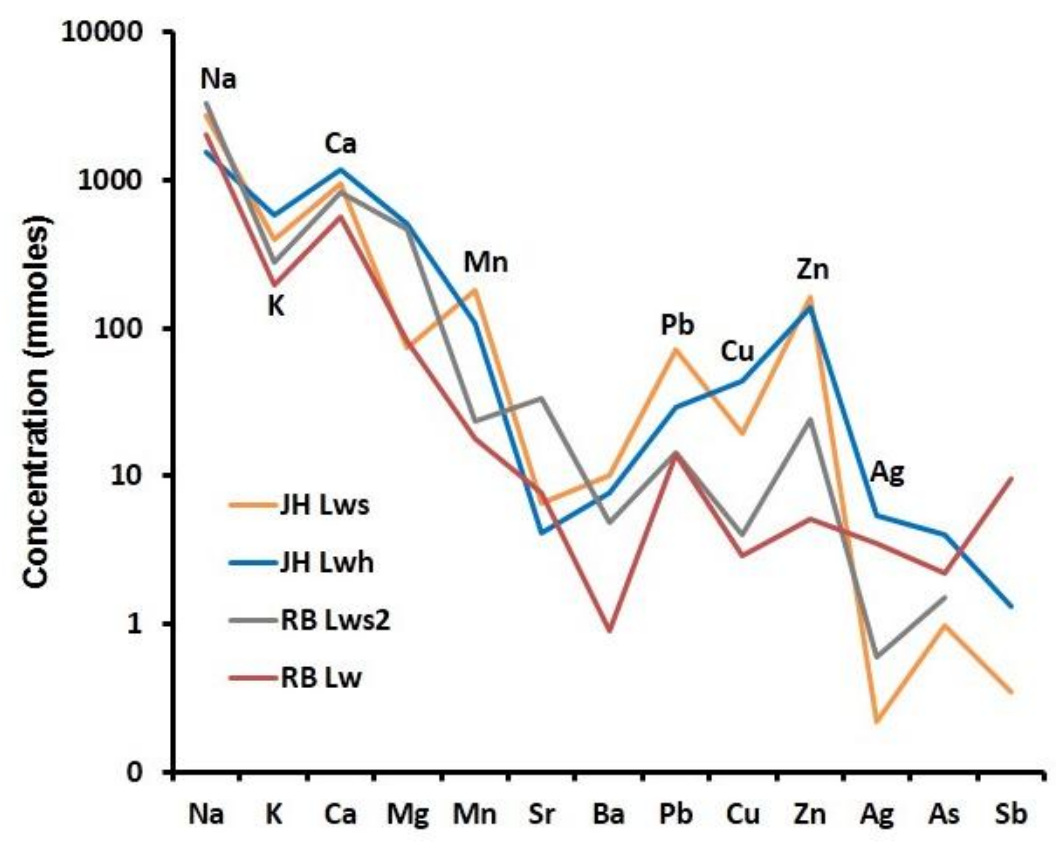

1023 Fig. 13. Comparison of the Jbel Haïmer brine compositions (JH Lws and JH Lwh brines) with 1024 the compositions of brines from the Roc Blanc silver deposit (RB Lws2 and RB Lw brines, 1025 from Essarraj et al., 2017a). 


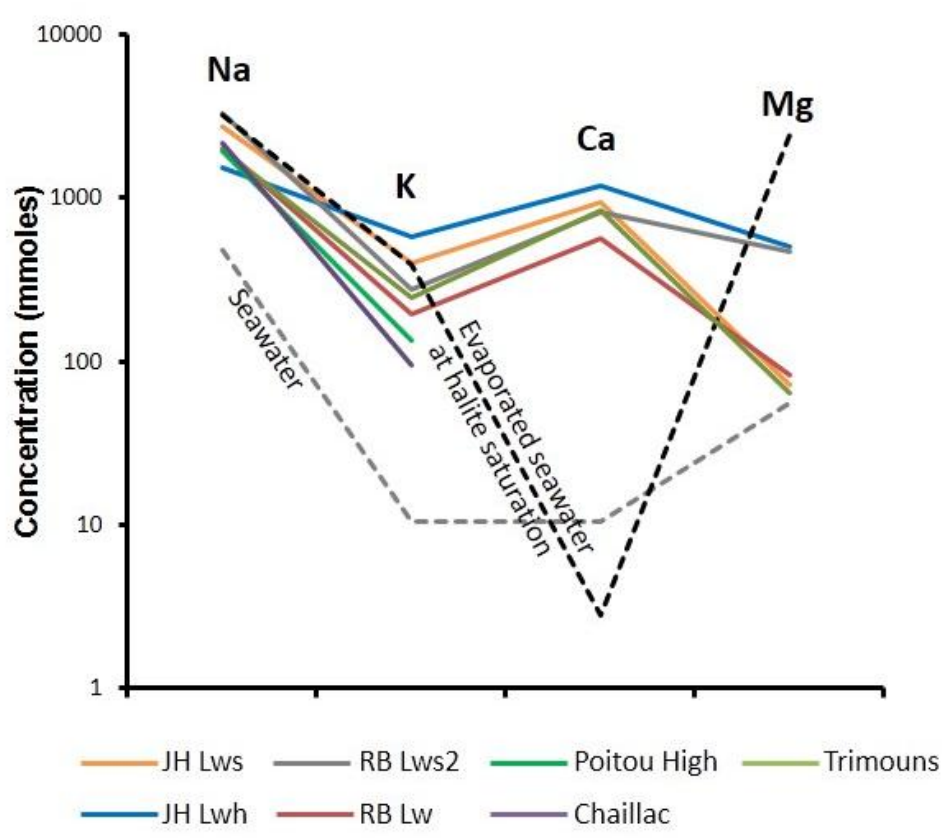

1027 Fig. 14. Average $\mathrm{Na}, \mathrm{K}, \mathrm{Ca}$ and Mg concentrations in fluids from Jbel Haïmer (JH Lws and JH 1028 Lwh brines, this study) and Roc Blanc (RB Lws2 and RB Lw brines, Essarraj et al, 2017a). For 1029 comparison, chemical composition of brines from literature are plotted: Poitou High and 1030 Chaillac (Boiron et al., 2002), Trimouns (Leisen et al., 2012b) as well seawater and evaporated 1031 seawater after halite saturation (Fontes and Matray, 1993). 

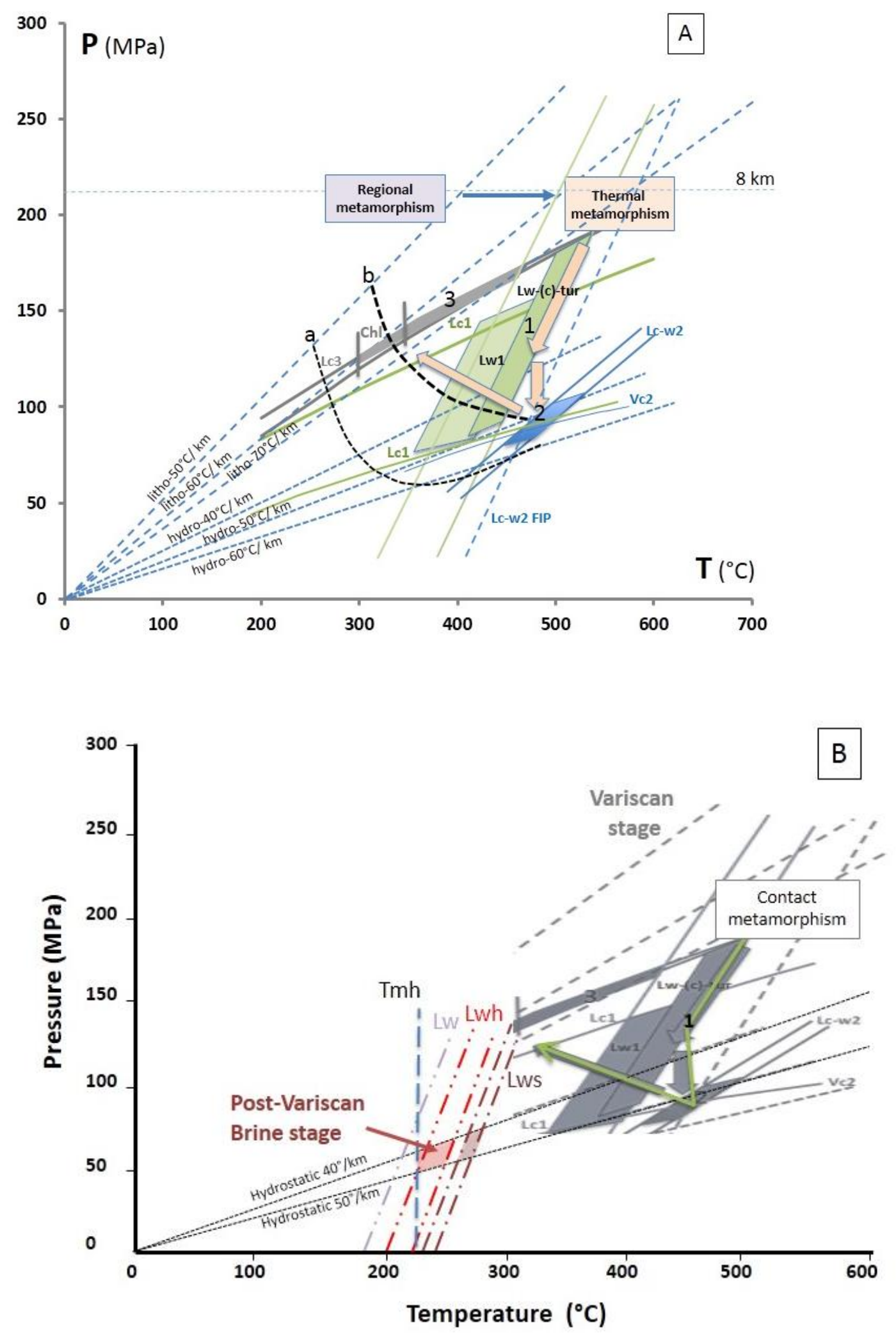

Fig. 15. P-T diagram for the two main stages at Jbel Haïmer with typical inclusions of each fluid inclusion type, distinguished by their colours: A Variscan stages; B Post-Variscan $\mathrm{Cu}$ base metal ore stage. Thermal gradients for the lithostatic and hydrostatic pressures are reported, as well as isopleths from Weisbrod (1984) for two compositions: (a) $10 \% \mathrm{CO}_{2}$ and 6 
$\% \mathrm{NaCl}$ and (b) $20 \% \mathrm{CO}_{2}$ and $6 \% \mathrm{NaCl}$. The thermal metamorphism box for the Central Jebilet is from Bastoul (1992). Chl: Roc Blanc chlorite temperature domain from Essarraj et al. (2017a). Arrows represent the evolution P-T trend. In Fig. 15B, the Variscan domain is shown in grey.

1044
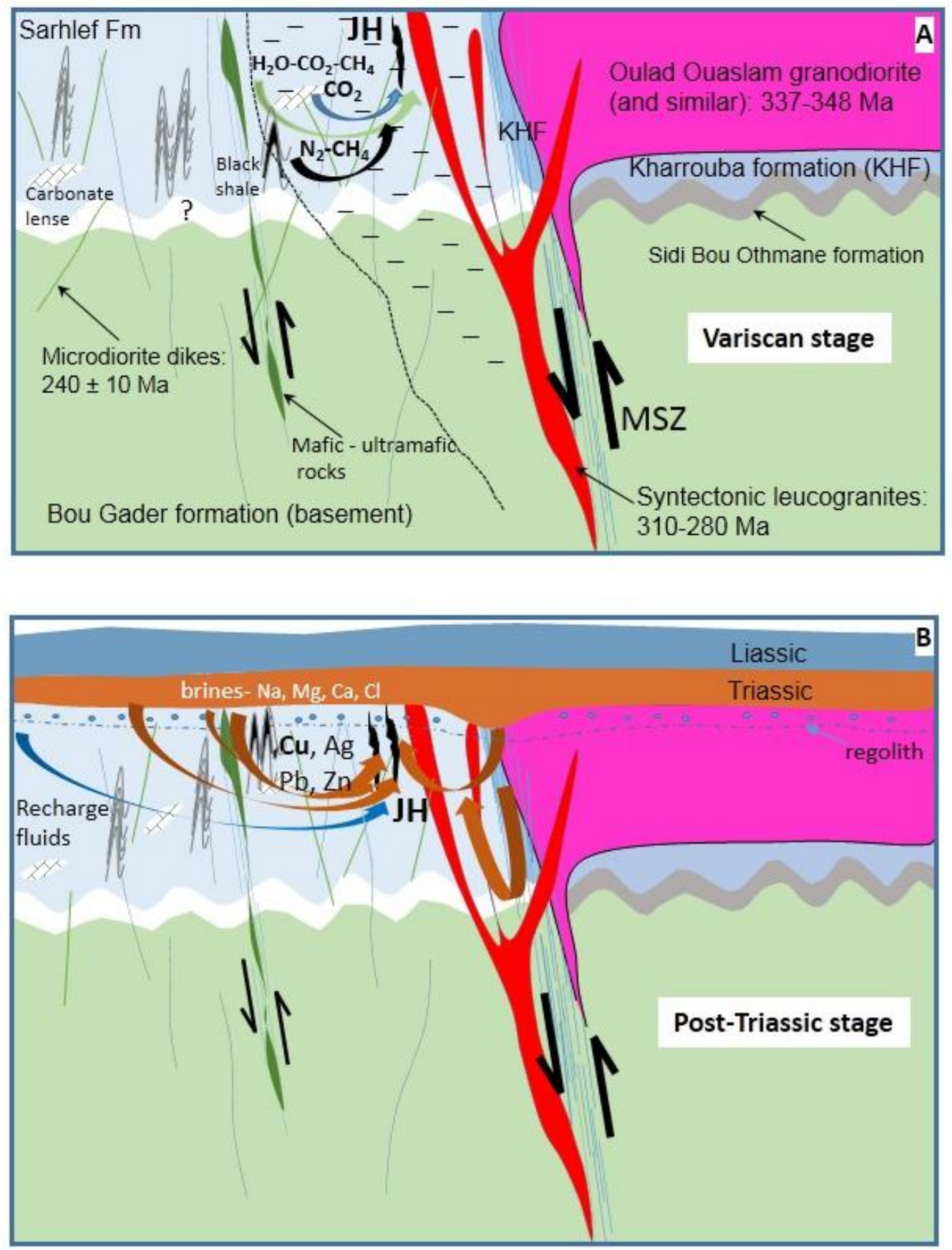

Fig. 16. A two-stage model of fluid circulation in the Jbel Haïmer area (JH) Jebilet: A Variscan stage: the intrusion of late leucogranites, the thermal metamorphism M2a lead to the genesis of $\mathrm{CO}_{2}, \mathrm{CH}_{4}-\mathrm{N}_{2}$ and $\mathrm{H}_{2} \mathrm{O}-\mathrm{CH}_{4}-\mathrm{CO}_{2}$ fluids which mix, and form, in pre-existing discontinuities, 
the early quartz assemblages with the Fe-As-Sn-(Bi) association. See text for references on the granodiorite, granite and microdiorite ages. MSZ: Marrakesh Sear Zone. B Mesozoic brine stage: after peneplaination and deposition of Triassic/Early Jurassic formations, circulation of brines coming from Triassic evaporite formation within the regolith, and several types of lithologies including black shales, basic intrusions and schists, yield to the extraction of metals, the transport and the formation of $\mathrm{Cu}$-polymetallic ores in the Jbel Haïmer area. Triassic and Liassic covering rocks in the Jebilet are from Saddiqi et al. (2009). Figures (A) and (B) are not to scale.

Table 1. Paragenetic sequence for the Jbel Haïmer occurrences.

\begin{tabular}{|c|c|c|c|c|c|}
\hline \multirow{2}{*}{\begin{tabular}{|ll} 
Minerals & Stages \\
\end{tabular}} & \multicolumn{3}{|c|}{ Pre ore stages } & \multicolumn{2}{|l|}{ Ore stages } \\
\hline & Sn-Bi stage & Fe-As-Co-Ni stage & Fe stage & $\mathrm{Cu}-\mathrm{Ag}-(\mathrm{Au})-$ base metals stages & Supergene \\
\hline \multirow{2}{*}{\multicolumn{6}{|c|}{$\begin{array}{l}\text { Quartz I (QI) } \\
\text { Biotite (chloritized: chlorite 1) }\end{array}$}} \\
\hline & \multicolumn{5}{|c|}{$\begin{array}{l}\text { Biotite (chloritized: chlorite 1) } \\
\text { Turmaline }\end{array}$} \\
\hline Turmaline & & & & & \\
\hline \multicolumn{6}{|l|}{ Muscovite } \\
\hline \multicolumn{6}{|l|}{ Cassiterite } \\
\hline \multicolumn{6}{|l|}{ Bi-minerals } \\
\hline \multicolumn{6}{|l|}{ Quartz (QII) } \\
\hline \multicolumn{6}{|l|}{ Pyrite } \\
\hline \multicolumn{6}{|l|}{ Arsenopyrite } \\
\hline \multicolumn{6}{|l|}{ Co-pyrite } \\
\hline \multicolumn{6}{|l|}{ Co-Fe-Ni-sullfarsenide } \\
\hline \multicolumn{6}{|l|}{ Quartz III (QIII) } \\
\hline \multicolumn{6}{|l|}{ Pyrrhotite } \\
\hline \multicolumn{6}{|l|}{ Chlorite 2} \\
\hline \multicolumn{6}{|l|}{ Feathery quartz } \\
\hline \multicolumn{6}{|l|}{ Carbonates } \\
\hline \multicolumn{6}{|l|}{ QIV } \\
\hline \multirow{2}{*}{\multicolumn{6}{|c|}{$\begin{array}{l}\text { Fe-Sphalerite } \\
\text { Chalcopyrite }\end{array}$}} \\
\hline & & & & $\mathbf{-}$ & \\
\hline \multicolumn{6}{|l|}{ Stannite } \\
\hline \multicolumn{6}{|l|}{ Bi-Te-Se sulphide } \\
\hline \multicolumn{6}{|l|}{ Galena } \\
\hline \multicolumn{6}{|l|}{ Natives: Ag-Au alloy } \\
\hline \multicolumn{6}{|l|}{ Malachite } \\
\hline \multicolumn{6}{|l|}{ Covellite } \\
\hline \multicolumn{6}{|l|}{ Fe-Oxides/hydroxides } \\
\hline \multicolumn{6}{|l|}{ Cerussite } \\
\hline \multicolumn{6}{|l|}{ Native metals } \\
\hline \multicolumn{6}{|l|}{$(\mathrm{Pb}, \mathrm{Zn}, \mathrm{Ag}, \mathrm{Cu}, \mathrm{Bi}, \mathrm{Se})$} \\
\hline Fluid circulations & $\mathrm{N} 2-\mathrm{CH}_{4}-\mathrm{CO}_{2}-\mathrm{H}_{2}$ & metamorphic fluids - & ariscan & Basinal brines (aqueous) - Triassic + & Meteoric Fluids \\
\hline
\end{tabular}


Table 2. Description of fluid inclusion types from Jbel Haïmer using nomenclature from Boiron et al. (1992) completed. L: liquid, V: vapour; (*): fluid inclusions homogenising to an aqueous

1065 liquid.

\begin{tabular}{|c|c|c|}
\hline Fluid inclusion type & Fluid inclusion description & \\
\hline LC & \multicolumn{2}{|c|}{ One-phase liquid N2-CH4-CO2 (carbonic: c) } \\
\hline Vc & \multicolumn{2}{|c|}{ One-phase vapor N2-CH4-CO2 (carbonic: c) } \\
\hline LC-w * & \multicolumn{2}{|c|}{ Two-phase aqueous (w) carbonic (c), liquid water dominated $+V$} \\
\hline$L w-(c) *$ & \multicolumn{2}{|c|}{ Two-phase liquid water dominated $+V$, with traces of gas (clathrates } \\
\hline Lws * & \multicolumn{2}{|c|}{ Multi-phase aqueous $(w) L+V+$ unidentified solids + halite } \\
\hline Lwh * & \multicolumn{2}{|c|}{ Multi-phase aqueous (w) $L+V+$ one solid + halite } \\
\hline $\mathrm{Lw} *$ & Two-phase liquid water dominated $+\mathrm{V}$ & \\
\hline
\end{tabular}

Table 3. Summary of microthermometry data of fluid inclusions from the Jbel Haïmer ores. $\mathrm{Tm} \mathrm{CO}_{2}$ : melting temperature of volatile phase, Th $\mathrm{CO}_{2}$ : homogenisation temperature of volatile phase to the liquid (L) or vapour (V), Tm cl: melting temperature of clathrate, Te: eutectic temperature, Tm ice: melting temperature of ice, Th: homogenisation temperature to 1072 the liquid (L) or vapour phase (V), Tm hh: melting temperature of hydrohalite, Tm h: melting

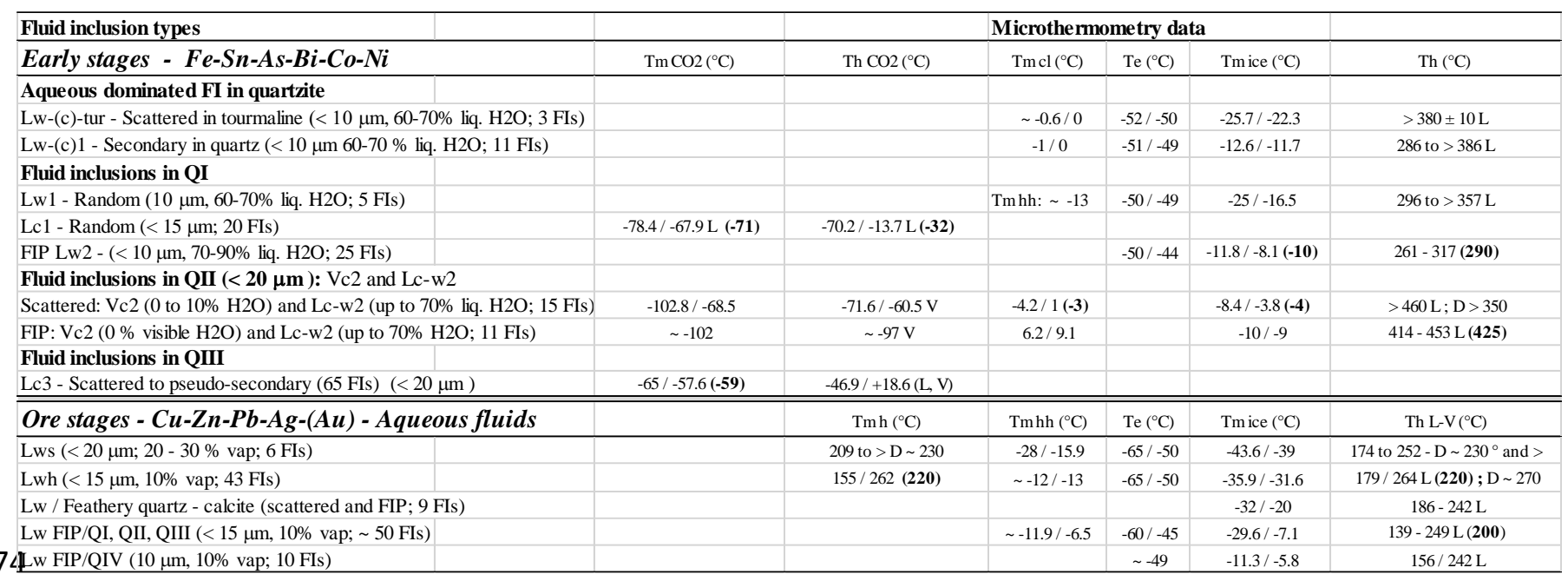


1082

1083

1084

1085

1086

1087

1088

1089

1090

1091

1092

1093

1094

1095

1096

1097

1098

1099

1100

1101

Table 4. Microthermometric and Raman data for carbonic and aqueous-carbonic fluid inclusions from Jbel Haïmer and the neighbouring Roc Blanc deposit (*Essarraj et al., 2017a).

Concentrations of the volatile phase components are given in mole \%. Vc1 and $\mathrm{Vc} 2$ are respectively early and late carbonic vapour fluid inclusions from Roc Blanc. (FIs: Fluid inclusion, nm: not measured)

\begin{tabular}{|l|l|c|c|c|c|c|}
\hline Deposit/Fluid inclusion type & FI reference & CO2 & CH4 & N2 & Tf CO2 & Th CO2 \\
\hline Jbel Haïmer & & & & & & \\
\hline Vc2 scattered/QII & L6-2A-P2-8 & 7.7 & 22.5 & 69.8 & -102.8 & $(\mathrm{~nm}) \mathrm{V}$ \\
\hline Vc2 ( 10\% H2O) scattered/QII & L6-2C-IF4 & 17.7 & 22.1 & 60.2 & -73.6 & $\sim$ \\
\hline Vc2 scattered/QII & L6-2C-IF5 & 18.6 & 23.8 & 57.6 & -82.1 & $(\mathrm{~nm}) \mathrm{V}$ \\
\hline Vc2 scattered/QII & L6-2A-P2-9 & 9.1 & 51.5 & 39.4 & -95.6 & $(\mathrm{~nm}) \mathrm{V}$ \\
\hline Lc-w2 scattered/recrystallised QII & L6-2A-P1-1 & 30.7 & 64.5 & 4.8 & $\sim-102$ & $-96.7 \mathrm{~V}$ \\
\hline Lc-w2 scattered/recrystallised QII & L6-2A-P1-2 & 23.8 & 70 & 6.2 & $(\mathrm{~nm})$ & $(\mathrm{nm}) \mathrm{V}$ \\
\hline Lc3 scattered QIII & JH4-1-IF19 & 58.5 & 12.2 & 29.3 & -59.6 & $-13.5 \mathrm{~L}$ \\
\hline Lc3 peudo-secondary QIII & JH4-1-IF1 & 88 & 1.7 & 10.3 & -59.5 & $-15.9 \mathrm{~L}$ \\
\hline Lc3 pseudosecondary QIII & JH4-1-IF5 & 83.7 & 4 & 12.3 & -58.2 & $+1.6 \mathrm{~L}$ \\
\hline \hline Roc Blanc * & & & & & & \\
\hline Vc1 & RB19/2 & 22.5 & 67.3 & 10.2 & $(\mathrm{~nm})$ & $(\mathrm{nm}) \mathrm{V}$ \\
\hline Vc1 & RB22/1-1 & 15.9 & 36.9 & 47.3 & -81.1 & $(\mathrm{~nm}) \mathrm{V}$ \\
\hline Vc1 & RB22/1-2 & 14.2 & 39.6 & 46.2 & -79.1 & $-106.8 \mathrm{~V}$ \\
\hline Vc1 & RB22/1-6 & 14.8 & 39.6 & 45.5 & -80.6 & $(\mathrm{~nm}) \mathrm{V}$ \\
\hline Vc2 & RB22/1-3 & 50.2 & 22.5 & 27.3 & -68.7 & $-51.8 \mathrm{~V}$ \\
\hline Vc2 & RB22/1-4 & 48.9 & 22 & 29.1 & -69 & $-51.3 \mathrm{~V}$ \\
\hline Vc2 & RB19B-1 & 58.2 & 19.1 & 22.8 & -60.8 & $-23.6 \mathrm{~V}$ \\
\hline Vc2 & RB19B-3 & 54 & 17.5 & 28.5 & -60.7 & $-24.7 \mathrm{~V}$ \\
\hline Vc2 & RB19B-5 & 51.2 & 17.7 & 31.1 & -59.2 & $(\mathrm{~nm}) \mathrm{V}$ \\
\hline
\end{tabular}


1102 Table 5. Representative LA-ICP-MS data obtained on Lws and Lwh fluid inclusions from the $1103 \mathrm{Cu}$ - stage (Jbel Haïmer). Absolute element concentrations are in $\mathrm{mmol} / \mathrm{kg}$ of solution in the 1104 first line, and ppm (second line, italic font).

\begin{tabular}{|c|c|c|c|c|c|c|c|c|c|c|c|c|c|c|c|}
\hline Fl type & FI number & $\mathrm{Na}$ & $\mathrm{K}$ & $\mathrm{Ca}$ & $\mathrm{Mg}$ & $\mathrm{Mn}$ & $\mathrm{Cu}$ & $\mathrm{Zn}$ & $\mathrm{Ag}$ & $\mathrm{Pb}$ & $\mathrm{Sb}$ & As & $\mathrm{Ba}$ & $\mathrm{Rb}$ & $\mathrm{Sr}$ \\
\hline \multirow[t]{20}{*}{ Lws } & JH3-6-1-IF1 & 2971 & 277 & 860 & 61 & 146 & 13.9 & 251.2 & 0.1 & 68.6 & 0.7 & 1.1 & 12.2 & 3.6 & 9.8 \\
\hline & & 68332 & 10814 & 34405 & 1452 & 8027 & 878 & 16577 & 7 & 14194 & 85 & 79 & 1698 & 310 & 861 \\
\hline & JH3-6-1-IF3 & 2284 & 649 & 601 & 97 & 183 & 4.9 & 244.9 & 0.2 & 228 & 0.3 & 0.9 & 4.5 & 3.1 & 4.3 \\
\hline & & 52539 & 25300 & 24034 & 2330 & 10072 & 311 & 16163 & 19 & 47196 & 42 & 64 & 623 & 265 & 377 \\
\hline & JH3-6-2-IF2 & 2542 & 415 & 1304 & 56 & 98 & 15.4 & 72.8 & nd & 32.2 & 0.2 & 2.0 & 3.7 & 0.8 & 3.7 \\
\hline & & 58473 & 16182 & 52148 & 1354 & 5401 & 973 & 4807 & $n d$ & 6658 & 26 & 149 & 519 & 72 & 322 \\
\hline & JH3-6-3-IF1 & 1753 & 388 & 1079 & 76 & 431 & 50.6 & 226.8 & 0.1 & 81.5 & 0.4 & 0.3 & 12.2 & 2.1 & 8.1 \\
\hline & & 40317 & 15126 & 43163 & 1817 & 23704 & 3185 & 14968 & 7 & 16870 & 50 & 21 & 1701 & 175 & 707 \\
\hline & JH3-6-4-IF4 & 3977 & 328 & 580 & 30 & 66 & 31.2 & 147.3 & 0.1 & 39.1 & 0.2 & 0.2 & 7.5 & 2.1 & 3.4 \\
\hline & & 91475 & 12806 & 23199 & 730 & 3655 & 1965 & 9720 & 14 & 8083 & 26 & 16 & 1042 & 182 & 299 \\
\hline & JH3-6-4-IF5 & 3539 & 354 & 706 & 3 & 125 & 0.3 & 213.0 & nd & 41 & 0.2 & nd & 12.5 & 2.8 & 7.3 \\
\hline & & 81400 & 13791 & 28238 & 71 & 6858 & 18 & 14058 & $n d$ & 8489 & 26 & nd & 1742 & 238 & 637 \\
\hline & JH3-6-7-IF1 & 1621 & 304 & 1139 & 69 & 471 & 17.4 & 212.5 & 1.0 & 108.0 & 0.4 & 0.7 & 29.8 & 1.9 & 9.3 \\
\hline & & 37291 & 11875 & 45570 & 1660 & 25912 & 1099 & 14028 & 103 & 22349 & 54 & 55 & 4145 & 163 & 812 \\
\hline & JH3-6-7-IF4 & 3245 & 376 & 632 & 121 & 212 & 7.3 & 180.2 & 0.1 & 68.3 & 0.4 & 0.3 & 13.2 & 2.6 & 7.4 \\
\hline & & 74646 & 14652 & 25284 & 2893 & 11674 & 462 & 11896 & 8 & 14143 & 53 & 19 & 1828 & 218 & 648 \\
\hline & JH3-6-8-IF1 & 1379 & 577 & 1803 & 109 & 71 & 21.7 & 29.8 & 0.1 & 27.1 & 0.2 & 1.5 & 3.1 & 2.0 & 9.3 \\
\hline & & 31724 & 22505 & 72103 & 2619 & 3923 & 1367 & 1969 & 7 & 5600 & 26 & 113 & 432 & 175 & 811 \\
\hline & JH3-6-8-IF3 & 4040 & 305 & 703 & 104 & 8 & 27.7 & 12.1 & nd & 28.3 & nd & 2.0 & 1.6 & nd & 2.3 \\
\hline & & 92916 & 11879 & 28120 & 2497 & 432 & 1748 & 801 & $n d$ & 5860 & $n d$ & 146 & 228 & nd & 198 \\
\hline \multirow[t]{12}{*}{ Lwh } & JH3-1-IF2 & 2201 & 686 & 826 & 559 & 51 & 45.1 & 66.6 & 6.6 & 52.4 & nd & nd & 7.7 & nd & 4.8 \\
\hline & & 50631 & 26761 & 33043 & 13418 & 2821 & 2839 & 4394 & 701 & 10854 & $n d$ & nd & 1074 & nd & 425 \\
\hline & JH3-2-IF3 & 1482 & 439 & 1519 & 380 & 63 & 43.2 & 75.9 & 3.0 & 16.7 & 0.4 & 3.8 & 4.4 & 0.8 & 2.7 \\
\hline & & 34086 & 17112 & 60749 & 9110 & 3473 & 2723 & 5007 & 322 & 3452 & 51 & 281 & 618 & 71 & 237 \\
\hline & JH3-2-IF5 & 1633 & 688 & 1429 & 108 & 155 & 51.3 & 146.3 & 4.7 & 24.1 & 0.5 & 4.7 & 2.9 & 1.2 & 4.3 \\
\hline & & 37558 & 26840 & 57164 & 2580 & 8502 & 3231 & 9656 & 506 & 4996 & 58 & 354 & 402 & 101 & 373 \\
\hline & JH3-4-IF1 & 1389 & 562 & 1047 & 682 & 84 & 45.5 & 146.4 & 2.5 & 34.1 & 0.5 & 5.1 & 2.9 & 1.3 & 2.2 \\
\hline & & 31956 & 21929 & 41878 & 16362 & 4620 & 2865 & 9664 & 267 & 7054 & 67 & 382 & 404 & 109 & 192 \\
\hline & JH3-4-IF4 & 1034 & 710 & 1507 & 532 & 42 & 30.5 & 33.1 & 6.5 & 22.6 & 0.4 & 2.8 & 0.9 & 2.0 & 4.3 \\
\hline & & 23778 & 27675 & 60279 & 12764 & 2319 & 1921 & 2186 & 691 & 4682 & 49 & 213 & 126 & 173 & 373 \\
\hline & JH3-5-IF1 & 1451 & 394 & 717 & 744 & 248 & 48.0 & 352.2 & 8.7 & 23.1 & 4.7 & 3.7 & 26.6 & 1.0 & 6.1 \\
\hline & & 33367 & 15385 & 28681 & 17853 & 13621 & 3023 & 23248 & 929 & 4785 & 578 & 279 & 3691 & 87 & 535 \\
\hline
\end{tabular}

Table 6. Comparison of LA-ICP-MS data obtained on brines from Jbel Haïmer and Ag-base metal brines from Roc Blanc (data from Essarraj et al., 2017a). Concentrations are in mmol/kg of solution in the first line, and ppm (second line, italic font).

\begin{tabular}{|l|c|c|c|c|c|c|c|c|c|c|c|c|c|}
\hline Fl Type & $\mathbf{N a}$ & $\mathbf{M g}$ & $\mathbf{K}$ & $\mathbf{C a}$ & $\mathbf{M n}$ & $\mathbf{S r}$ & $\mathbf{A g}$ & $\mathbf{B a}$ & $\mathbf{P b}$ & $\mathbf{C u}$ & $\mathbf{Z n}$ & $\mathbf{A s}$ & $\mathbf{S b}$ \\
\hline Lws Jbel Haïmer & 2735 & 73 & 397 & 941 & 181 & 6.5 & 0.2 & 10 & 72.2 & 19.1 & 159.1 & 1 & 0.4 \\
\hline & 62877 & 1774 & 15522 & 37713 & 9944 & 570 & 22 & 1373 & 14960 & 1214 & 10402 & 75 & 49 \\
\hline Lwh Jbel Haïmer & 1532 & 501 & 580 & 1174 & 107 & 4.1 & 5.3 & 7.6 & 28.8 & 43.9 & 136.8 & 4 & 1.3 \\
\hline & 35220 & 12177 & 22677 & 47052 & 5878 & 359 & 572 & 1044 & 5967 & 2790 & 8944 & 300 & 158 \\
\hline Lws2 Roc Blanc & 3303 & 470 & 274 & 819 & 24 & 33.2 & 0.6 & 4.8 & 14.3 & 4 & 24.1 & 1.5 & nd \\
\hline & 75924 & 11417 & 10730 & 32814 & 1301 & 2909 & 65 & 659 & 2963 & 254 & 1576 & 112 & $n d$ \\
\hline Lw Roc blanc & 2047 & 82 & 196 & 564 & 18 & 7.7 & 3.5 & 0.9 & 14 & 2.9 & 5.1 & 2.2 & 9.6 \\
\hline & 47060 & 1993 & 7663 & 22604 & 989 & 675 & 378 & 124 & 2901 & 184 & 333 & 165 & 1169 \\
\hline
\end{tabular}



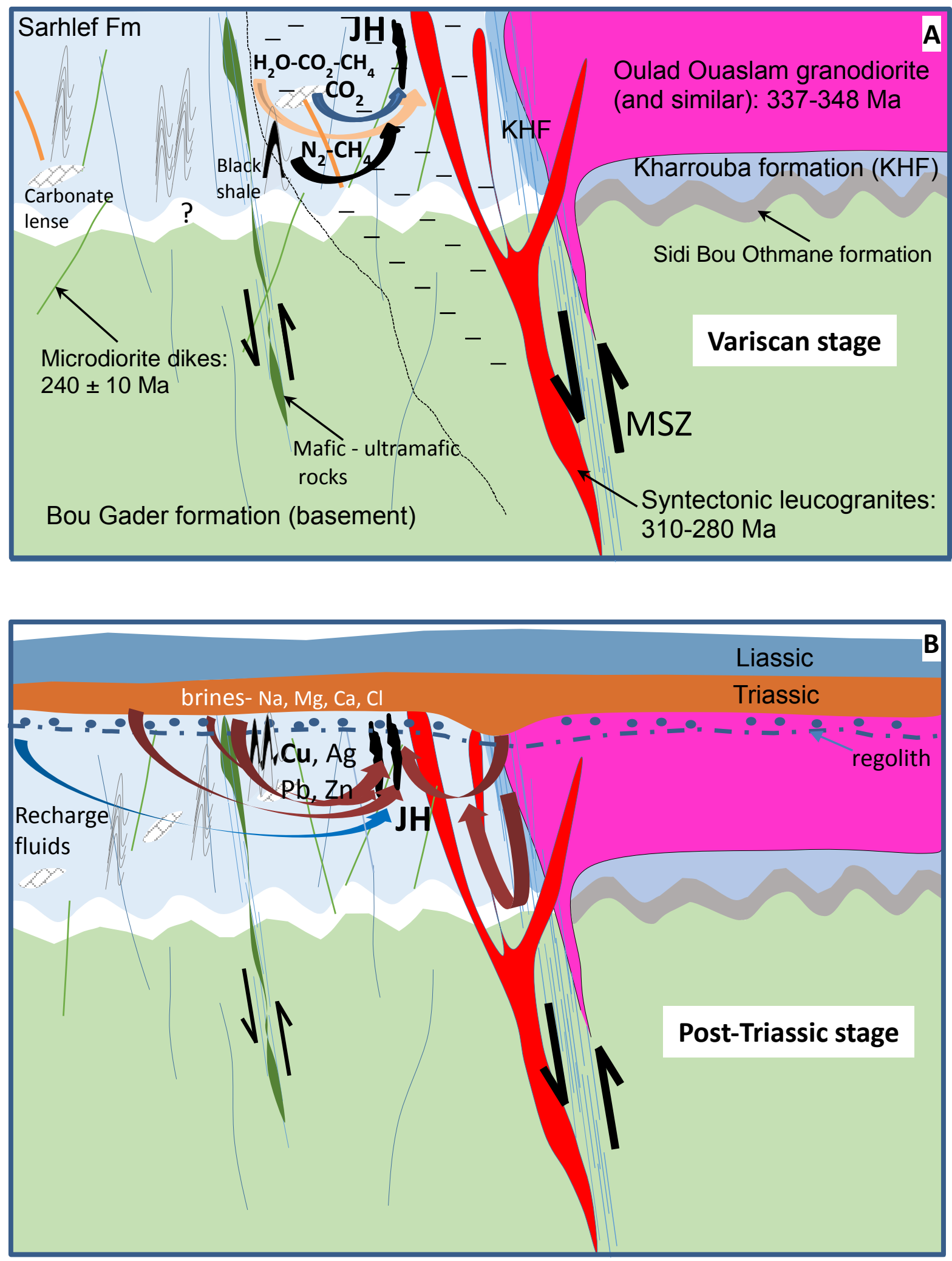